\title{
Corporal punishment, discipline and social norms: A systematic review in low- and middle-income countries
}

\author{
Michelle Lokot*, Amiya Bhatia, Leah Kenny, Beniamino Cislaghi \\ London School of Hygiene \& Tropical Medicine, 15-17 Tavistock Place, London WC1H 9SH, United Kingdom
}

\section{A R T I C L E I N F O}

\section{Keywords:}

Corporal punishment

Child discipline

Social norms

Systematic review

\begin{abstract}
A B S T R A C T
There is increased recognition that incorporating a social norms approach provides insights for understanding corporal punishment and/or discipline (CPD). This review seeks to explore how the literature analyses social norms and CPD in low- and middle-income countries (LMICs). We searched eight electronic databases, Google Scholar, Google and institutional websites, including articles in LMICs which examined social norms and CPD perpetrated by family members or teachers. Data was extracted, assessed for quality and analyzed according to key themes. Of 21,708 articles from academic databases and 92 from other sources, 37 studies were included. We observed heterogeneity in study design, and in the definition and measurement of social norms. In the majority of studies, social norms supporting CPD were either harmful or, at times, protective. The review also finds that gender, age, power hierarchies and changes such as conflict, migration and modernization may influence norms on CPD. CPD interventions should be evaluated over longer periods and with consideration to the continuum of violence between homes and schools. Future research on CPD should (1) theorize and define social norms more clearly; (2) examine both harmful and protective norms linked to CPD; (3) explicitly examine perpetration of violence across the home-school continuum.
\end{abstract}

\section{Introduction}

Corporal punishment is the most common form of violence experienced by children (UNICEF, 2014). The Committee on the Rights of the Child General Comment 8, define it as "any punishment in which physical force is used and intended to cause some degree of pain or discomfort, however light" (United Nations Committee on the Rights of the Child, 2006). Corporal punishment is often equated with spanking (Gershoff \& Grogan-Kaylor, 2016), but may also include other physical acts like kicking, spanking, slapping, shaking, pushing, punching, hitting and burning (UNICEF, 2014). The terms "discipline" or "violent discipline" are sometimes also used to recognize that physical violence is not the only form of punishment children experience. UNICEF states that both corporal punishment and violent psychological discipline (which includes acts like: threats, humiliation, ridicule, withdrawing love, and intimidation) are "violations of children's rights" which "tend to overlap and frequently occur together, exacerbating the short- and long-term harm they inflict" (UNICEF, 2014). In this review, to acknowledge the harms caused by both physical and psychological punishment and the power dynamics between adults and children that drive all forms of punishment, we use the term, "corporal punishment and/or discipline" ("CPD"). This refers to any form of physical and/or psychological punishment used against children in the home or school environment.

As Stith et al. (2009) recognized, the global literature on CPD tends to focus on the individual characteristics of the parent and the child, neglecting the broader ecological context influencing children's lives. In line with this, much research on CPD has demonstrated the negative impact it can have on children's health and wellbeing (Gershoff \& Grogan-Kaylor, 2016). For instance, CPD can increase children's antisocial behavior (M.A. Straus, Sugarman, \& Giles-Sims, 1997), or result in substance abuse (Lau et al., 2005), depression (Turner \& Muller, 2004), future perpetration of intimate partner violence (Straus \& Yodanis, 1996), and decreased cognitive ability (M.A. Straus \& Paschall, 2009). Another stream of research has looked at individuallevel risk factors for parents who use CPD as a form of discipline. These parents are more likely to have experienced childhood abuse (Ferrari, 2002), physical punishment during childhood (Rodriguez \& Sutherland, 1999) and maternal depression (Eamon, 2001), and are more likely to have low income (Dietz, 2000) and low educational attainment (Dietz, 2000). A small body of research shows that gender roles and expectations can result in boys being punished more frequently than girls (Lansford et al., 2010; Mehlhausen-Hassoen, 2019) and some systematic reviews examine the effects of interventions and laws on CPD

\footnotetext{
* Corresponding author.

E-mail address: michelle.lokot@lshtm.ac.uk (M. Lokot).
} 
(Larzelere, 1996; Moon, Damman, \& Romero, 2018; Valdebenito, Eisner, Farrington, Ttofi, \& Sutherland, 2018; Zolotor \& Puzia, 2010). Although these studies provide initial evidence of how contextual factors affect CPD, they do not examine the role of norms in sustaining CPD.

\subsection{Using social norms theory to understand $C P D$}

Social norms theory comes in assistance to those who want to expand the understanding of the contextual factors contributing to CPD. Social norms are rules of appropriate action shared by members of a group (Legros \& Cislaghi, 2019). Despite the fact that social norms theory is multi-faceted and at times contradictory, in child protection work the most-used definition is that offered by Cialdini, Reno, \& Kallgren (1990) of social norms as one's beliefs about 1) what others in one's group do (descriptive norms), and 2) what others in one's group approve of (injunctive norms). Social norms influence practices through several mechanisms, the most common being the desire to seek social rewards and avoid social punishments for, respectively, compliance and non-compliance with the norm (e.g. if others disapprove of me, they might isolate me).

Four theoretical premises related to social norms theory are relevant for our review. First, social norms can have different strengths: they make a practice obligatory (people are strongly influenced, almost forced, to comply with it), appropriate (people think it is in their best interest to comply, even though social pressure is reduced), or acceptable (pressure to comply, but no sanctioning for not doing so) (Cislaghi \& Heise, 2018a). Second, norms can be internalized; internalization being the process through which people integrate the appropriateness of a given norm (Bicchieri, 2006). Third, norms intersect with other contextual factors (such as services, laws, or access to resources) in ways that can reduce or increase their strength (Cislaghi, Heise, 2018a; Rimal \& Lapinksi, 2015). Finally, there exists an extremely powerful and almost omnipresent type of social norms called gender norms. While feminist scholars have advanced the thinking on gender norms independently from social norms theory, Cislaghi and Heise (2019) have recently offered a definition that harmonizes social norms theory and gender theory: "Gender norms are social norms defining acceptable and appropriate actions for women and men in a given group or society. They are embedded in formal and informal institutions, nested in the mind, and produced and reproduced through social interaction."

In child protection research and practice, although corporal punishment is the most prevalent form of violence against children, there is little research on how social and gender norms influence corporal punishment. Social norms theory has, however, been used extensively to explain other issues, for example, compliance with the practices of child marriage and female genital cutting in low- and middle- income countries (LMIC) (Kalamar, Lee-Rife, \& Hindin, 2016; Mackie, 1996; UNICEF, 2005). As attention to social norms in other areas of child protection increased, a body of research is emerging on how changing social norms may reduce CPD (Fleckman, Taylor, Theall, \& Andrinopoulos, 2019; Lilleston, Goldmann, Verma, \& McCleary-Sills, 2017; Taylor, Hamvas, Rice, Newman, \& DeJong, 2011). However, the literature lacks a review of this emerging body of work on social norms and CPD. In this systematic review we examine the relationship between social norms and CPD, specifically in low- and middle-income countries (LMICs). This is a mixed methods review, which, like other similar reviews, does not include meta-analysis to statistically compare quantitative data due to differing methodological approaches taken by included articles (Mallett, Hagen-Zanker, Slater, \& Duvendack, 2012). Our work thus uses qualitative synthesis based on thematic analysis to answer three research questions: 1) How do social norms contribute to making CPD acceptable in LMIC? 2) What other contextual factors may influence social norms and CPD? 3) How do norm change interventions address the social norms sustaining CPD?
Table 1

Search terms.

\begin{tabular}{|c|c|c|c|}
\hline $\begin{array}{l}\text { Corporal punishment and } \\
\text { discipline }\end{array}$ & Child & Perpetrator & Location \\
\hline $\begin{array}{l}\text { "Corporal punishment" } \\
\text { Punish* } \\
\text { Disciplin* } \\
\text { Punitive } \\
\text { Smack* } \\
\text { Slap* } \\
\text { Caning } \\
\text { Cane** } \\
\text { Spank* }\end{array}$ & $\begin{array}{l}\text { Child* } \\
\text { Girl* } \\
\text { Boy* } \\
\text { Adolescen* } \\
\text { Teen* } \\
\text { Youth* } \\
\text { Toddler* } \\
\text { Infant* } \\
\text { Baby } \\
\text { Babies }\end{array}$ & $\begin{array}{l}\text { Parent* } \\
\text { Caregiv* } \\
\text { Teacher* } \\
\text { "School staff" } \\
\text { Adult** } \\
\text { Family } \\
\text { Families } \\
\text { Familial } \\
\text { Mother* } \\
\text { Father* } \\
\text { Sibling* } \\
\text { Sister* } \\
\text { Brother* } \\
\text { Grandpa* } \\
\text { Grandfather* } \\
\text { Grand-father* } \\
\text { Grandm* } \\
\text { Grand-mother* } \\
\text { Aunt* } \\
\text { Uncle* } \\
\text { Relative* } \\
\text { Cousin* } \\
\text { In-law* } \\
\text { Step-* } \\
\text { Stepfather* } \\
\text { Stepmother* } \\
\text { Stepparent* }\end{array}$ & $\begin{array}{l}\text { Street*" } \\
\text { Road* } \\
\text { Private } \\
\text { Public } \\
\text { Domestic } \\
\text { Home* } \\
\text { House* } \\
\text { School* } \\
\text { "Educational } \\
\text { facilit"" }\end{array}$ \\
\hline
\end{tabular}

\section{Methods}

We searched eight academic databases: Medline, PsycINFO, Social Policy \& Practice, Academic Search Complete, Web of Science, Scopus, IBSS and Cochrane Library (see Table 1 for the terms used in the searches). The database searches were conducted in April 2019. To address publication bias (Adams, Smart, \& Huff, 2017) and to avoid excluding the knowledge produced by institutions working on child protection issues, we decided to include grey literature in our review, including assessments, baselines, evaluations and other reports. We used Google and Google Scholar to supplement the academic literature search and to identify grey literature, using the search terms: "corporal punishment" AND "research", and "child discipline" AND "research" (see Table 1 below or Appendix A: Supplementary materials). Results were limited to 200 hits per search term. We also hand-searched institutional websites, using a variety of adapted search terms (e.g. "punishment", “discipline", "corporal punishment", "child violence", "child protection") due to the limited search functionality of many of these websites. The websites searched were child rights organisations and general knowledge repositories, specifically: CPC Network, Eldis, Global Initiative to End all Corporal Punishment of Children, Human Rights Watch, Innocenti Research Centre, Overseas Development Institute, Plan International, ReliefWeb, Save the Children and UNICEF. In addition, we requested literature from academics and practitioners. We also hand-searched the reference lists of included studies. The study protocol was peer-reviewed by a librarian at the London School of Hygiene and Tropical Medicine and finalized based on their recommendations. The protocol was registered with PROSPERO (CRD42019133828).

\subsection{Inclusion and exclusion criteria}

Articles from any time period were included if they were in English, carried out in LMICs and examined social norms and CPD that was (1) perpetrated by family members or teachers, and (2) occurred within homes, schools, and public places. Screening occurred in two stages using Covidence. First, we screened titles and abstracts. In order to 
ground the research in empirical findings, we excluded book chapters, book reviews, conference proceedings, literature reviews, opinion pieces, news articles, letters to editors, manuals, toolkits and blogs. Studies related to violence against children which were not about corporal punishment or violent discipline, or which examined CPD perpetrated by other children, or occurred in residential institutions were also excluded. More specifically, literature about sexual abuse of children; transactional sex; peer-to-peer violence or bullying at school; violence in care homes, orphanages or boarding schools; and violence in the juvenile justice or penal system were excluded. We excluded studies from high-income countries. We used World Bank classifications of low- and middle-income countries issued in June 2018 to make determinations on the status of each country. In the first stage of screening, $10 \%$ of the peer-reviewed articles were double-screened with 98\% agreement between the first and second author. The first and second authors then conducted title and abstract screening separately. The first author screened $75 \%$ of the articles.

We revised our stated PROSPERO search strategy during the fulltext screening. We decided to only include articles with the term "norm" instead of other words we had planned to also search, including attitude, belief, behavior, gender, culture, tradition, custom, religion, expectation, value, rule, assumption, moral, social, sanction, perception, acceptable. Given the large number of articles included during screening, we decided to focus on just the sub-sample of articles that refer to norms. To be included for data extraction, articles had to include findings on CPD related to norms. Overall, $14 \%$ of articles included for full text screening were double-screened with $95 \%$ agreement reached between the first and third author. The first and third authors then conducted the word searches independently. The first author screened $63 \%$ of the articles. Where multiple records by the same author existed for the same research (e.g. a dissertation and article), only the earliest record was kept. Although articles which did not refer to norms but used norms-adjacent words were not included in extraction and were outside the scope of this review, we wanted to better understand how literature that referenced norms also used other norms-related constructs, so we searched each included article for these words and tagged these articles.

\subsection{Data analysis}

For each article, we extracted information based on the following categories: (a) study methodology (qualitative (including ethnography), quantitative (including RCT) mixed methods, experiment); (b) research aim; (c) country; (d) sample size (age, sex); (e) whether the study listed limitations, assessed bias or discussed reflexivity; (f) type of violence; $(\mathrm{g})$ measures used to define violence; (h) intervention type (if applicable); (i) major theoretical analysis and results on norms and CPD; (j) major theoretical analysis and results on norms-related terms; (k) donor. We conducted data extraction and quality assessment simultaneously using Microsoft Excel. Authors one, two and three participated in independent extraction and $48 \%$ of articles were checked to ensure consistency in the extraction process. We then analyzed extracted data to understand (1) the range of study methodologies and countries included; (2) whether and how studies defined CPD; (3) how social norms and norms-related words were theorized; (4) key themes on the links between norms and punishment/discipline in the study findings; and (5) the design of interventions to prevent or respond to CPD. Qualitative synthesis based on key themes emerging across studies was used to understand the scope of the literature instead of a more traditional meta-analysis, given the methodological diversity across studies (Mallett et al., 2012).

\section{Results}

\subsection{Final sample}

Out of 21,708 results from 8 academic databases, 7650 were duplicates, resulting in 14,058 unique records being screened. Of papers excluded during screening, most (88\%) were excluded for irrelevance, or because they were from a high-income country $(22 \%)$. Alongside the academic database records, 92 additional records were identified and screened from Google Scholar $(n=31)$, Google $(n=11)$ and institutional websites $(n=50)$. The reference lists of included articles were hand-searched and 7 further articles were included in the full-text review, but none were deemed eligible. Researchers and practitioners were also invited to submit studies that fit the criteria. In total, 6 individuals submitted 8 articles. After screening, 4 of these were included in the full-text review, but none of these were deemed eligible. We also conducted additional searches to determine how many articles could have been included in full-text screening if the review included articles in French and Spanish. Across the eight databases, our search yielded 880 articles in these two languages. During the first stage of screening, 859 were excluded - only 21 would make it to the full-text review. We assessed 699 full-text papers for eligibility. Of these, 566 studies (81\%) were excluded due to no, or vague, references to norms (i.e. norms only being mentioned in passing, without analysis), and 99 (14\%) were excluded as they referred only to norms-related constructs. In total, 37 studies (5\%) which included empirical findings on norms were included. Fig. 1 outlines the process at different stages using the PRISMA framework.

\subsection{Description of included studies}

\subsubsection{Study types and designs}

The 37 included articles consisted of 29 peer-reviewed journal articles, $1 \mathrm{PhD}$ thesis, and 7 articles which were classified as grey literature (see Table 1 for details). Included studies on social norms and CPD were published between 1978 and 2019, with the bulk of studies ( $n=31$ ) published between 2010 and 2019. 12 studies (32\%) used quantitative methods, $8(22 \%)$ studies used qualitative methods, 6 (16\%) used ethnographic methods, $6(16 \%)$ used mixed methods, 4 $(11 \%)$ were randomized control trials and $1(3 \%)$ used an experiment.

\subsubsection{Study contexts}

Overall, 31 studies were conducted in a single country and 6 studies covered multiple countries, some of which included a mix of high-, middle- and low-income countries. Data for the high-income countries was not extracted. Single or dual country studies covered 22 countries: 5 in Uganda, 2 in Bangladesh, China, India, Kenya, South Africa and Vietnam, and 1 in Bolivia, Botswana, Democratic Republic of Congo, Ghana, Guyana, Haiti, Lebanon, Lesotho, Morocco, Pakistan, Palestine, Philippines, Rwanda, Thailand and Turkey. The multiple-country studies included a smaller study of primary research covering Cambodia, Indonesia, Papua New Guinea, Sri Lanka and Nepal, as well as a long list of countries of a further 37 countries where only large-scale population data from governments and the United Nations was analyzed (see Table 2 below).

\subsubsection{Definitions and measures of $C P D$}

In total, 19 studies (51\%) defined punishment or discipline in terms of physical violence, $11(30 \%)$ defined it as incorporating multiple forms of violence (physical and psychological/emotional violence), and 7 studies (19\%) did not provide a clearly stated definition for punishment or discipline. This lack of conceptual clarity or uniformity in the definitions contributed to our use of "CPD" as a broader term covering either or both kinds of punishment. Of the studies that used a broad definition encompassing both physical and psychological/emotional violence, 4 studies (36\%) (Kyegombe et al., 2017; Liu \& Wang, 2018; 

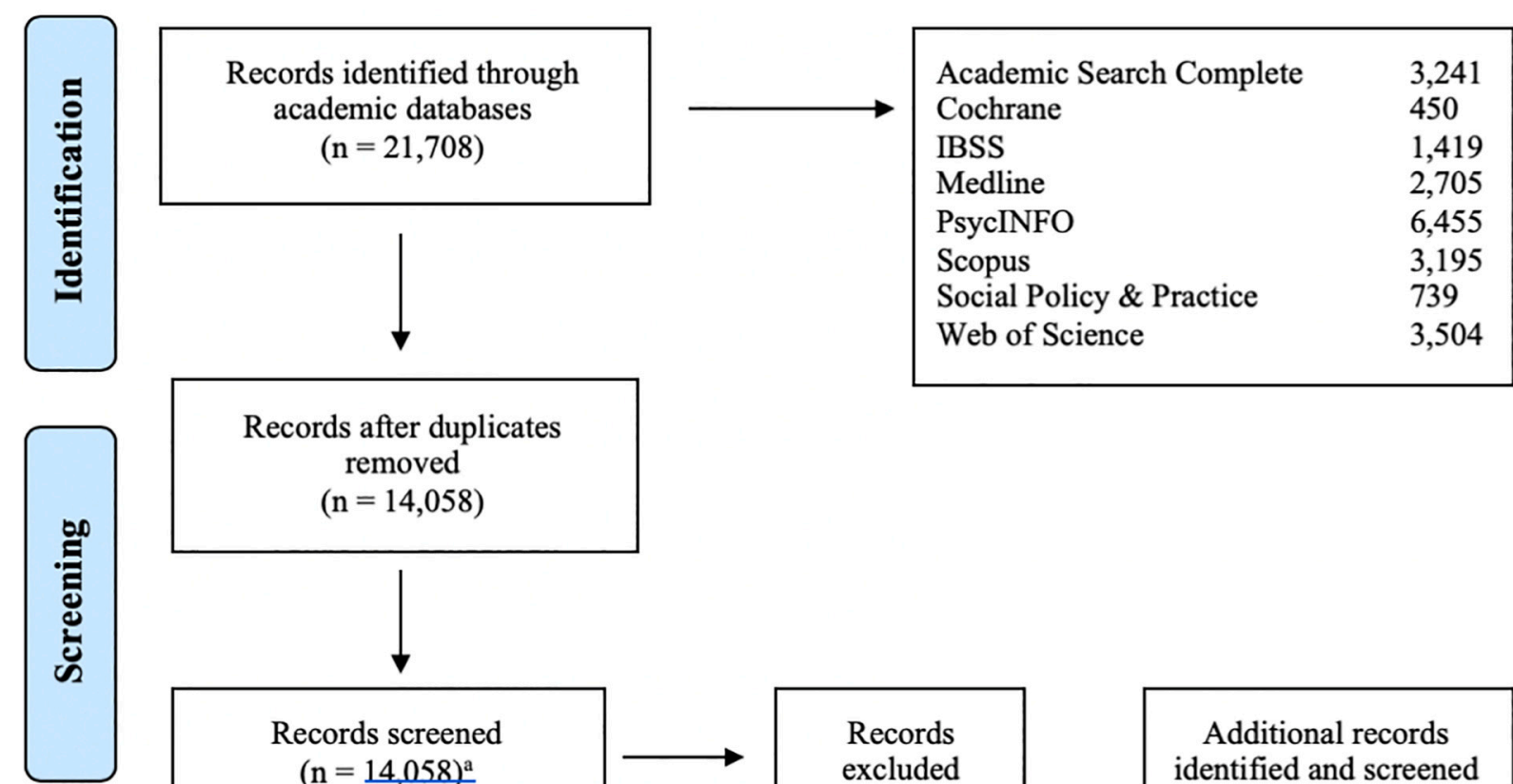

Records after duplicates removed $(\mathrm{n}=14,058)$
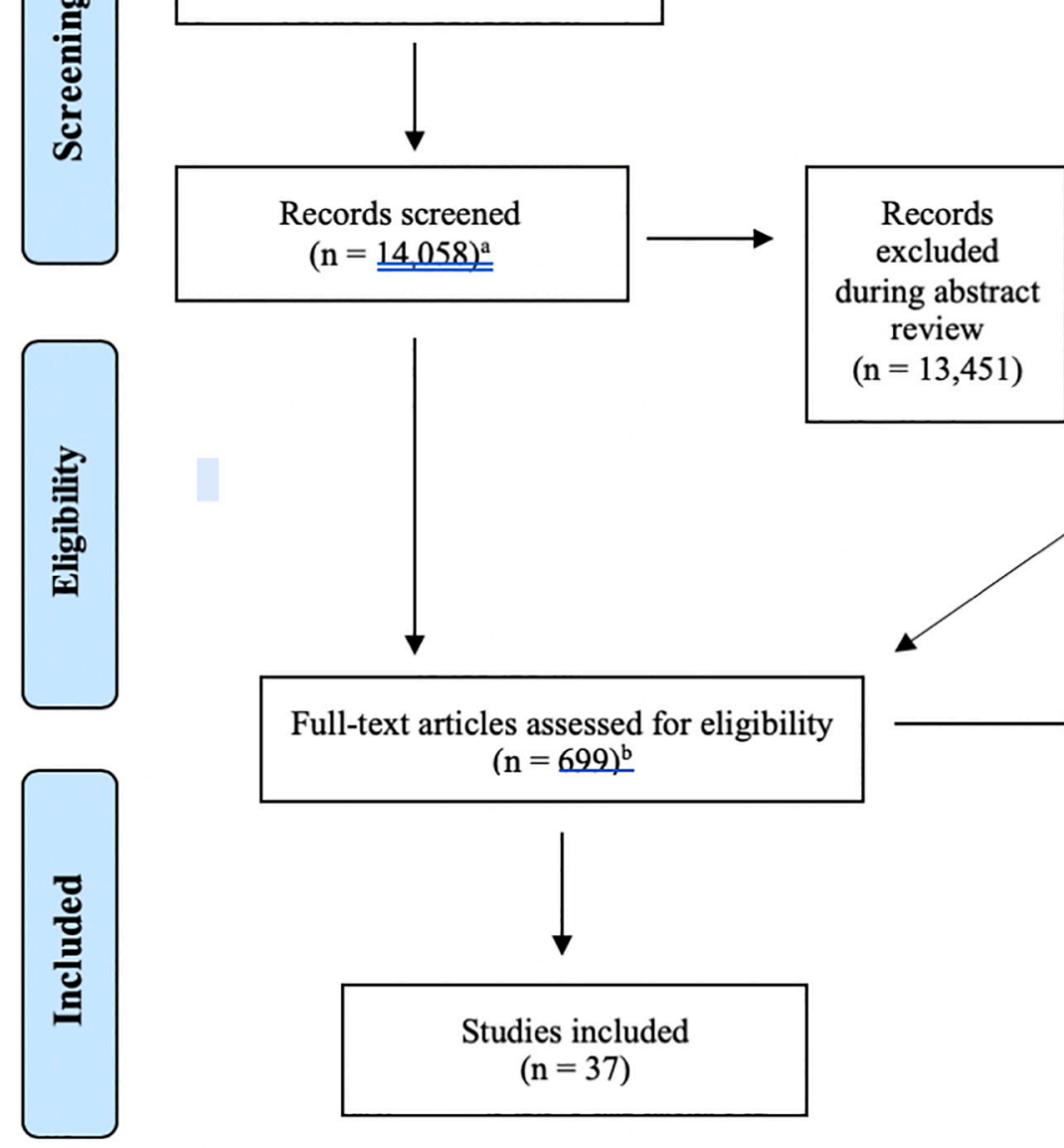

Full-text articles assessed for eligibility $(\mathrm{n}=699)^{\mathrm{b}}$

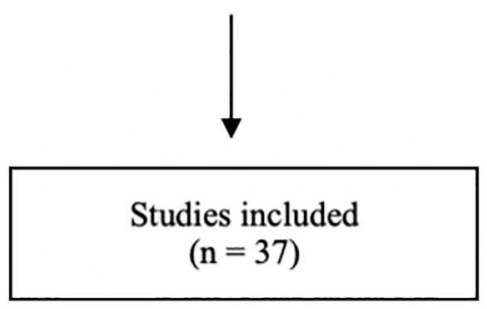

1,419

2,705

6,455

3,195

3,504

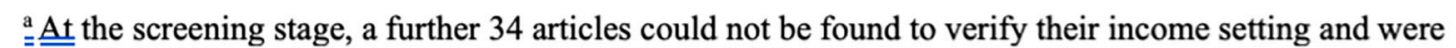
excluded. This applied particularly to unpublished $\mathrm{PhD}$ theses, journal articles whose journals were no longer in publication, or journal which were only print journals (not online).

${ }^{\mathrm{b}}$ At the full-text stage, a further 36 articles could not be found for the reasons above, thus were excluded.

Fig. 1. Study selection and review process, based on PRISMA guidance, http://www.prisma-statement.org.

Morrow \& Singh, 2014; Stark et al., 2018) then chose to measure punishment or discipline as being only physical.

Almost half of the studies (particularly the quantitative, mixed method and randomized control studies) used multiple measures for CPD, using existing tools like the Conflict Tactics Scale. Very few qualitative and ethnographic studies specified ways of measuring CPD, relying instead on qualitative accounts of violence described by children, parents and teachers. In 19 (51\%) studies, CPD was viewed within a wider study into violence in homes and schools, making it difficult to draw conclusions about CPD norms.

3.2.4. Perpetration and positioning of CPD

Overall, 18 of the studies (49\%) focused on violence perpetrated by multiple actors, $11(30 \%)$ focused on violence perpetrated by parents, and $8(21 \%)$ focused on violence perpetrated by teachers. Studies focused on punishment in the home (38\%), punishment in both the home and school setting (32\%), punishment in school (27\%), or do not have a set focus (2.7\% - representing one study, which was an experiment). In 
Table 2

Included studies $(n=37)$.

\begin{tabular}{|c|c|c|c|c|c|c|c|c|c|c|}
\hline Authors & Year & Title & Methods & Aim & Country & Sample & $\begin{array}{l}\text { Type of } \\
\text { violence }\end{array}$ & $\begin{array}{l}\text { Location } \\
\text { of } \\
\text { violence }\end{array}$ & Perpetrator & $\begin{array}{l}\text { References to norms in } \\
\text { results/discussion }\end{array}$ \\
\hline $\begin{array}{l}\text { Minturn, Boyd, \& } \\
\text { Kapoor }\end{array}$ & 1978 & $\begin{array}{l}\text { Increased } \\
\text { maternal power } \\
\text { status: Changes } \\
\text { in socialization } \\
\text { in a restudy of } \\
\text { Raijut mothers } \\
\text { of Khalapur, } \\
\text { India }\end{array}$ & Qualitative & $\begin{array}{l}\text { To understand } \\
\text { changes in } \\
\text { mothers' } \\
\text { socialization } \\
\text { practices }\end{array}$ & India & $\begin{array}{l}24 \text { women in } \\
1955 \text { and } 38 \\
\text { women in } \\
1975\end{array}$ & $\begin{array}{l}\text { Not } \\
\text { stated }\end{array}$ & Home & Multiple & $\begin{array}{l}\text { 'The changes in } \\
\text { socialization practices } \\
\text { are interpreted as } \\
\text { resulting from changes } \\
\text { in maternal roles } \\
\text { brought about by an } \\
\text { increase in the power } \\
\text { status of mothers. These } \\
\text { changes have, in turn, } \\
\text { been brought about by } \\
\text { the increased education } \\
\text { of women, } \\
\text { modernisation of social } \\
\text { norms regarding purdah } \\
\text { restrictions, and the } \\
\text { prosperity resulting from } \\
\text { high-yield grains and } \\
\text { increased emphasis on } \\
\text { profitably marketable } \\
\text { agriculture'. }\end{array}$ \\
\hline $\begin{array}{l}\text { Wilson, Wilson, \& } \\
\text { Fox }\end{array}$ & 2002 & $\begin{array}{l}\text { Structural and } \\
\text { personal } \\
\text { contexts of } \\
\text { discipline } \\
\text { orientations of } \\
\text { Guyanese } \\
\text { parents: } \\
\text { Theoretic and } \\
\text { empirical } \\
\text { considerations }\end{array}$ & Quantitative & $\begin{array}{l}\text { To obtain } \\
\text { descriptive, } \\
\text { personal and } \\
\text { social } \\
\text { information on } \\
\text { the discipline } \\
\text { style of urban } \\
\text { Guyanese } \\
\text { parents }\end{array}$ & Guyana & 340 parents & Multiple & Home & Parent & $\begin{array}{l}\text { 'Theoretically, the } \\
\text { gendered context of } \\
\text { discipline observed in } \\
\text { these data may indicate } \\
\text { a more generalized norm } \\
\text { in the Caribbean region'. }\end{array}$ \\
\hline $\begin{array}{l}\text { Dawes, De Sas } \\
\quad \text { Kropiwnicki, } \\
\text { Kafaar, \& } \\
\text { Richter }\end{array}$ & 2005 & $\begin{array}{l}\text { Corporal } \\
\text { punishment of } \\
\text { children: A } \\
\text { South African } \\
\text { national survey }\end{array}$ & Quantitative & $\begin{array}{l}\text { To understand } \\
\text { the prevalence } \\
\text { of partner } \\
\text { violence and } \\
\text { corporal } \\
\text { punishment as } \\
\text { well as } \\
\text { attitudinal and } \\
\text { demographic } \\
\text { predictors of } \\
\text { these } \\
\text { phenomena }\end{array}$ & South Africa & $\begin{array}{l}2497 \text { aged } 16 \\
\text { and over } \\
\text { ( } 41 \% \text { male } \\
\text { and } 59 \% \\
\text { female) }\end{array}$ & Physical & Multiple & Multiple & $\begin{array}{l}\text { 'Single strategy } \\
\text { interventions that focus } \\
\text { on changing individual } \\
\text { attitudes and behavior } \\
\text { are unlikely to meet with } \\
\text { success. This is because } \\
\text { the predictors of both } \\
\text { forms of violence } \\
\text { contain a mix of } \\
\text { influences, and because } \\
\text { both are strongly shaped } \\
\text { by prevailing norms and } \\
\text { local practices'. }\end{array}$ \\
\hline $\begin{array}{l}\text { Lansford, Chang, } \\
\text { Dodge, Malone, } \\
\text { Oburu, } \\
\text { Palmérus, } \\
\text { Bacchini, } \\
\text { Pastorelli, } \\
\text { Bombi, Zelli, } \\
\text { Tapanya, } \\
\text { Chaudhary, } \\
\text { Deater-Deckard, } \\
\text { Manke, \& Quinn }\end{array}$ & 2005 & $\begin{array}{l}\text { Physical } \\
\text { discipline and } \\
\text { children's } \\
\text { adjustment: } \\
\text { cultural } \\
\text { normativeness } \\
\text { as a moderator }\end{array}$ & Qualitative & $\begin{array}{l}\text { To examine if } \\
\text { normativeness } \\
\text { of child } \\
\text { discipline } \\
\text { moderates for } \\
\text { use of discipline } \\
\text { and children's } \\
\text { adjustment }\end{array}$ & $\begin{array}{l}\text { China, India, } \\
\text { Italy, Kenya, } \\
\text { the } \\
\text { Philippines, } \\
\text { and } \\
\text { Thailand }\end{array}$ & $\begin{array}{l}336 \text { mother- } \\
\text { child dyads - } \\
\text { Children and } \\
\text { their mothers } \\
\text { in China } \\
\text { ( } \mathrm{n}=50 ; 46 \% \\
\text { girls); India } \\
(n=46 ; 59 \% \\
\text { girls); Kenya } \\
(n=49 ; 55 \% \\
\text { girls); } \\
\text { Philippines } \\
\text { ( } n=50 ; 38 \% \\
\text { girls); and, } \\
\text { Thailand } \\
(n=60 ; 55 \% \\
\text { girls; total } \\
N=336) \text {. }\end{array}$ & Physical & Home & Parent & $\begin{array}{l}\text { '...experiencing high } \\
\text { levels of physical } \\
\text { discipline is related to } \\
\text { more adjustment } \\
\text { problems, but perceived } \\
\text { normativeness and } \\
\text { actual normativeness } \\
\text { moderate the association } \\
\text { between mothers' use of } \\
\text { physical discipline and } \\
\text { child ag- gression and } \\
\text { anxiety... countries with } \\
\text { the lowest normative use } \\
\text { of physical discipline } \\
\text { show the strongest } \\
\text { positive association } \\
\text { between individual } \\
\text { mothers' use of physical } \\
\text { discipline and their } \\
\text { children's behavior } \\
\text { problems'. }\end{array}$ \\
\hline Humphreys & 2008 & $\begin{array}{l}\text { Gendering } \\
\text { corporal } \\
\text { punishment: } \\
\text { beyond the } \\
\text { discourse of } \\
\text { human rights }\end{array}$ & $\begin{array}{l}\text { Qualitative } \\
\text { (Ethnography) }\end{array}$ & $\begin{array}{l}\text { To understand } \\
\text { how corporal } \\
\text { punishment is a } \\
\text { gendered } \\
\text { practice }\end{array}$ & Botswana & $\begin{array}{l}\text { Ethnography } \\
\text { - no sample } \\
\text { size stated }\end{array}$ & Multiple & School & Teacher & $\begin{array}{l}\text { 'As corporal punishment } \\
\text { was administered for } \\
\text { even the most trivial } \\
\text { matters... so violence } \\
\text { became trivialized. Its } \\
\text { reported everyday } \\
\text { occurrence ensured too } \\
\text { (continued on next page) }\end{array}$ \\
\hline
\end{tabular}


Table 2 (continued)

\begin{tabular}{|c|c|c|c|c|c|c|c|c|c|c|}
\hline Authors & Year & Title & Methods & Aim & Country & Sample & $\begin{array}{l}\text { Type of } \\
\text { violence }\end{array}$ & $\begin{array}{l}\text { Location } \\
\text { of } \\
\text { violence }\end{array}$ & Perpetrator & $\begin{array}{l}\text { References to norms in } \\
\text { results/discussion }\end{array}$ \\
\hline Archambault & 2009 & $\begin{array}{l}\text { Pain with } \\
\text { punishment and } \\
\text { the negotiation } \\
\text { of childhood: an } \\
\text { ethnographic } \\
\text { analysis of } \\
\text { children's rights } \\
\text { process in } \\
\text { Maasailand }\end{array}$ & $\begin{array}{l}\text { Qualitative } \\
\text { (Ethnography) }\end{array}$ & $\begin{array}{l}\text { To provide an } \\
\text { ethnographic } \\
\text { analysis of } \\
\text { corporal } \\
\text { punishment }\end{array}$ & Kenya & $\begin{array}{l}\text { Ethnography } \\
\text { - no sample } \\
\text { size stated }\end{array}$ & Physical & School & Teacher & $\begin{array}{l}\text { that it became routinized } \\
\text { and normalized.' } \\
\text { 'Most teachers in Enkop } \\
\text { schools are local Maasai, } \\
\text { which closely connects } \\
\text { the school to community } \\
\text { norms and } \\
\text { expectations...Teachers } \\
\text { take their position in the } \\
\text { social structure as } \\
\text { parents and elders and } \\
\text { believe in corporal } \\
\text { punishment's } \\
\text { pedagogical, } \\
\text { developmental and } \\
\text { social function'. }\end{array}$ \\
\hline Twum-Danso & 2010 & $\begin{array}{l}\text { Children's } \\
\text { Perceptions of } \\
\text { Physical } \\
\text { Punishment in } \\
\text { Ghana }\end{array}$ & Mixed & $\begin{array}{l}\text { To explore the } \\
\text { extent to which } \\
\text { children } \\
\text { in Ghana accept } \\
\text { their role in } \\
\text { society to be } \\
\text { disciplined by } \\
\text { the various } \\
\text { adults in their } \\
\text { lives }\end{array}$ & Ghana & $\begin{array}{l}158 \text { ( } 83 \text { boys } \\
\text { and } 75 \text { girls) }\end{array}$ & Physical & Multiple & Multiple & $\begin{array}{l}\text { 'Because of the } \\
\text { distinctions that } \\
\text { communities make } \\
\text { between discipline and } \\
\text { abuse many adult } \\
\text { participants in the FGDs } \\
\text { reported that they felt } \\
\text { able to, and very often } \\
\text { did, intervene if they } \\
\text { saw } \\
\text { relatives, friends or } \\
\text { neighbors exceeding the } \\
\text { cultural norm when } \\
\text { punishing their } \\
\text { children'. }\end{array}$ \\
\hline UNICEF & 2010 & $\begin{array}{l}\text { Child } \\
\text { disciplinary } \\
\text { practices at } \\
\text { home. Evidence } \\
\text { from a range of } \\
\text { low-and middle- } \\
\text { income } \\
\text { countries }\end{array}$ & Quantitative & $\begin{array}{l}\text { To analyse } \\
\text { findings on } \\
\text { child discipline } \\
\text { from } 35 \text { MICS } \\
\text { and DHS } \\
\text { surveys }\end{array}$ & $\begin{array}{l}33 \\
\text { countries }_{*}\end{array}$ & $\begin{array}{l}\text { 180,273 } \\
\text { (unweighted) }\end{array}$ & Multiple & Home & Multiple & $\begin{array}{l}\text { 'The mothers/primary } \\
\text { caregivers' belief that } \\
\text { proper child rearing } \\
\text { requires physical } \\
\text { punishment proved to be } \\
\text { strongly associated with } \\
\text { the prevalence of violent } \\
\text { discipline. This points to } \\
\text { the importance of } \\
\text { addressing attitudes and } \\
\text { norms in society } \\
\text { regarding child rearing } \\
\text { and child discipline in } \\
\text { order to change } \\
\text { behaviors'. }\end{array}$ \\
\hline Sanapo \& Nakamura & 2011 & $\begin{array}{l}\text { Gender and } \\
\text { physical } \\
\text { punishment: the } \\
\text { Filipino } \\
\text { children's } \\
\text { experience }\end{array}$ & Mixed & $\begin{array}{l}\text { To present } \\
\text { Filipino } \\
\text { children's } \\
\text { experiences of } \\
\text { physical } \\
\text { punishment, } \\
\text { their thoughts } \\
\text { in relation to } \\
\text { why they were } \\
\text { punished and } \\
\text { how they felt } \\
\text { towards the } \\
\text { adults who } \\
\text { punished them. }\end{array}$ & Philippines & $\begin{array}{l}270 \\
\text { (106 boys and } \\
123 \text { girls with } \\
\text { some data } \\
\text { missing) }\end{array}$ & Physical & Home & Parent & $\begin{array}{l}\text { 'The high prevalence } \\
\text { rate of physical } \\
\text { punishment among } \\
\text { grade- six students in } \\
\text { Iloilo could be attributed } \\
\text { to the fact that social and } \\
\text { legal norms in the } \\
\text { country consider } \\
\text { physical punishment as } \\
\text { not only acceptable but } \\
\text { also expected of } \\
\text { responsible parents'. }\end{array}$ \\
\hline $\begin{array}{l}\text { Ngakane, } \\
\text { Muthukrishna, \& } \\
\text { Ngcobo }\end{array}$ & 2012 & $\begin{array}{l}\text { Experiencing } \\
\text { violence in } \\
\text { schools: voices } \\
\text { of learners in } \\
\text { the Lesotho } \\
\text { context }\end{array}$ & Qualitative & $\begin{array}{l}\text { To explore } \\
\text { students' } \\
\text { experiences of } \\
\text { school violence }\end{array}$ & Lesotho & $\begin{array}{l}15 \text { ( } 8 \text { boys } \\
\text { and } 7 \text { girls) }\end{array}$ & $\begin{array}{l}\text { Not } \\
\text { stated }\end{array}$ & School & Multiple & $\begin{array}{l}\text { 'The findings in the } \\
\text { study reveal that the } \\
\text { deep rooted influence in } \\
\text { learner experiences of } \\
\text { gender violence is } \\
\text { gender inequality... } \\
\text { Gender equality should } \\
\text { permeate the school } \\
\text { culture, curriculum, } \\
\text { formal and informal } \\
\text { teaching practices, and } \\
\text { should target both boys } \\
\text { and girls'. }\end{array}$ \\
\hline
\end{tabular}


Table 2 (continued)

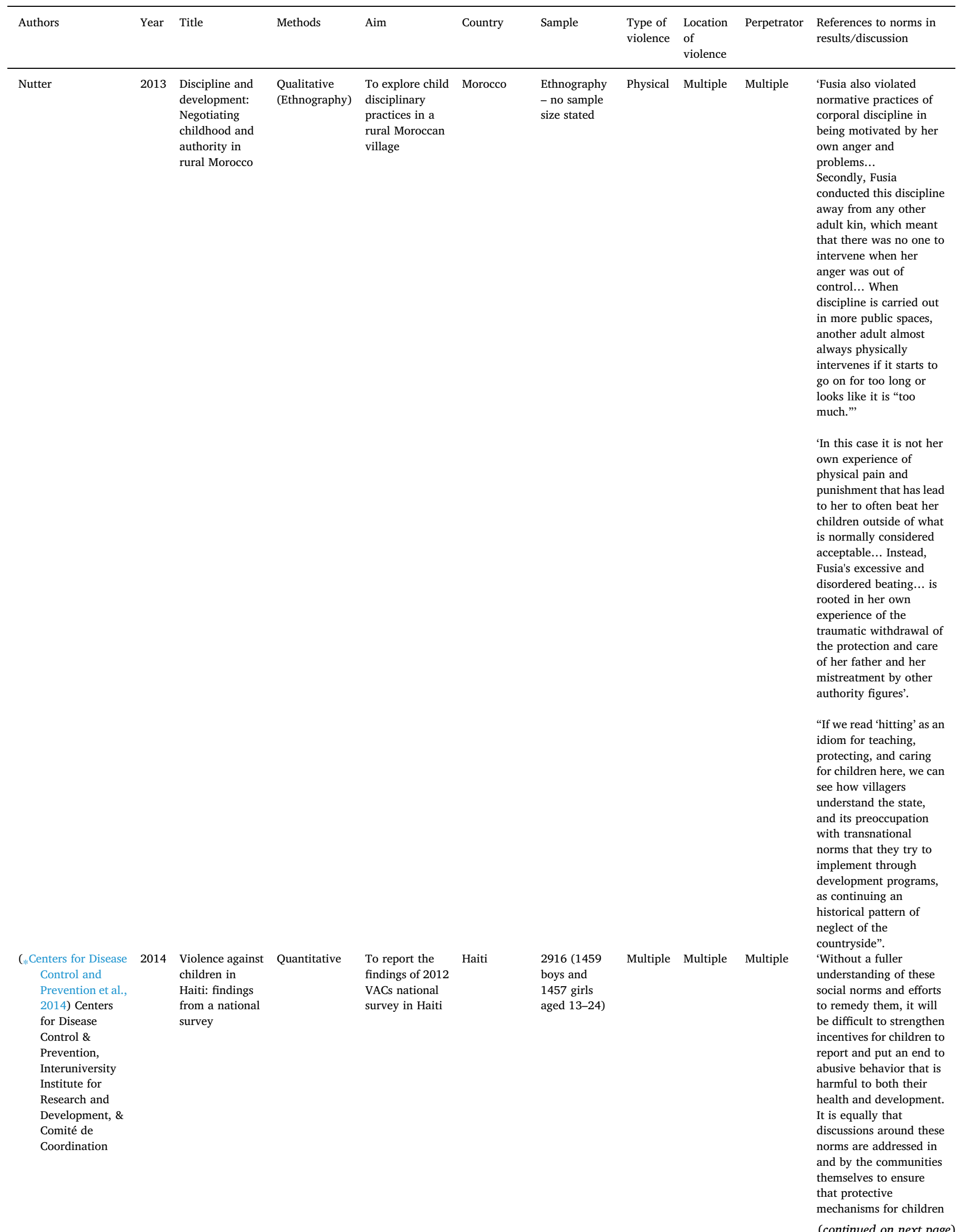


Table 2 (continued)

\begin{tabular}{|c|c|c|c|c|c|c|c|c|c|c|}
\hline Authors & Year & Title & Methods & Aim & Country & Sample & $\begin{array}{l}\text { Type of } \\
\text { violence }\end{array}$ & $\begin{array}{l}\text { Location } \\
\text { of } \\
\text { violence }\end{array}$ & Perpetrator & $\begin{array}{l}\text { References to norms in } \\
\text { results/discussion }\end{array}$ \\
\hline $\begin{array}{c}\text { International Center } \\
\text { for Research on } \\
\text { Women \& Plan } \\
\text { International }\end{array}$ & 2014 & $\begin{array}{l}\text { Are schools safe } \\
\text { and gender } \\
\text { equal spaces? } \\
\text { Findings from a } \\
\text { baseline study } \\
\text { of school related } \\
\text { gender-based } \\
\text { violence in five } \\
\text { countries in } \\
\text { Asia }\end{array}$ & Mixed & $\begin{array}{l}\text { To present } \\
\text { findings from a } \\
\text { baseline study } \\
\text { carried out in } \\
\text { specific districts } \\
\text { of five } \\
\text { Asian countries: } \\
\text { Cambodia, } \\
\text { Indonesia, } \\
\text { Nepal, Pakistan } \\
\text { and Vietnam, as } \\
\text { part of a } \\
\text { programme to } \\
\text { address School } \\
\text { Related Gender } \\
\text { based Violence } \\
\text { (SRGBV) in the } \\
\text { region. }\end{array}$ & $\begin{array}{l}\text { Cambodia, } \\
\text { Indonesia, } \\
\text { Nepal, } \\
\text { Pakistan, } \\
\text { Vietnam }\end{array}$ & $\begin{array}{l}137 \text { FGDs } \\
\text { with adults, } \\
133 \text { FGDs } \\
\text { with children, } \\
9103 \text { children } \\
\text { surveyed } \\
\text { ( } 4517 \text { boys } \\
\text { and } 4586 \\
\text { girls) }\end{array}$ & Multiple & School & Multiple & $\begin{array}{l}\text { are found and can be } \\
\text { strengthened within } \\
\text { Haitian culture, rather } \\
\text { than imposing values } \\
\text { from outside'. } \\
\text { '...the norms of } \\
\text { appropriate gender } \\
\text { related behavior for girls } \\
\text { and boys have already } \\
\text { been internalized by } \\
\text { students even at an early } \\
\text { adolescence stage. Boys } \\
\text { already have a sense of } \\
\text { masculine privileges and } \\
\text { rights that needs to be } \\
\text { discussed and } \\
\text { challenged', }\end{array}$ \\
\hline $\begin{array}{l}\text { Lansford, Deater- } \\
\text { Deckard, } \\
\text { Bornstein, } \\
\text { Putnick, \& } \\
\text { Bradley }\end{array}$ & 2014 & $\begin{array}{l}\text { Attitudes } \\
\text { justifying } \\
\text { domestic } \\
\text { violence predict } \\
\text { endorsement of } \\
\text { corporal } \\
\text { punishment and } \\
\text { physical and } \\
\text { psychological } \\
\text { aggression } \\
\text { towards } \\
\text { children: A } \\
\text { study in } 25 \text { low- } \\
\text { and middle- } \\
\text { income } \\
\text { countries }\end{array}$ & Quantitative & $\begin{array}{l}\text { To explore how } \\
\text { attitudes on } \\
\text { domestic } \\
\text { violence are } \\
\text { linked to } \\
\text { corporal } \\
\text { punishment, } \\
\text { and how norms } \\
\text { are linked to } \\
\text { children's } \\
\text { experiences of } \\
\text { violence }\end{array}$ & $\begin{array}{l}25 \\
\text { countries }_{* *}\end{array}$ & $\begin{array}{l}85,999 \\
\text { caregivers }\end{array}$ & Multiple & Home & Parent & $\begin{array}{l}\text { 'individual caregiver's } \\
\text { own attitudes about } \\
\text { domestic violence and } \\
\text { corporal punishment } \\
\text { showed a weaker } \\
\text { association with } \\
\text { children's experience of } \\
\text { psychological aggression } \\
\text { and physical violence } \\
\text { than was the case for } \\
\text { countries where there } \\
\text { was less overall societal } \\
\text { endorsement of domestic } \\
\text { violence and corporal } \\
\text { punishment. One } \\
\text { explanation for this } \\
\text { finding is that in } \\
\text { countries where } \\
\text { domestic violence and } \\
\text { corporal punishment are } \\
\text { widely accepted, harsh } \\
\text { behaviors towards } \\
\text { children may be parents' } \\
\text { default responses, less } \\
\text { guided by individual } \\
\text { choices regarding } \\
\text { discipline strategies than } \\
\text { by adoption of common } \\
\text { social practices'. }\end{array}$ \\
\hline Morrow \& Singh & 2014 & $\begin{array}{l}\text { Corporal } \\
\text { punishment in } \\
\text { schools in } \\
\text { Andhra } \\
\text { Pradesh, India: } \\
\text { children's and } \\
\text { parents' views }\end{array}$ & Mixed & $\begin{array}{l}\text { To explore } \\
\text { prevalence of } \\
\text { school corporal } \\
\text { punishment in } \\
\text { Andhra Pradesh }\end{array}$ & India & $\begin{array}{l}877 \text { children } \\
\text { surveyed } \\
\text { and } 30 \\
\text { children and } \\
\text { families } \\
\text { interviewed. } \\
\text { Household } \\
\text { survey: } \\
\text { Unknown }\end{array}$ & Physical & School & Teacher & $\begin{array}{l}\text { 'Our analysis of data } \\
\text { shows that corporal } \\
\text { punishment is widely } \\
\text { used in schools in } \\
\text { Andhra Pradesh... This } \\
\text { needs to be understood } \\
\text { in the context of social } \\
\text { norms related to how } \\
\text { children should be } \\
\text { brought up, and what } \\
\text { schooling should be like' }\end{array}$ \\
\hline $\begin{array}{l}\text { (*VanderEnde et al., } \\
\text { 2014) } \\
\text { VanderEnde, } \\
\text { Amin, \& Naved }\end{array}$ & 2014 & $\begin{array}{l}\text { Community- } \\
\text { level correlates } \\
\text { of physical } \\
\text { violence against } \\
\text { unmarried } \\
\text { female } \\
\text { adolescents in } \\
\text { Bangladesh }\end{array}$ & Quantitative & $\begin{array}{l}\text { To explore the } \\
\text { correlates of } \\
\text { physical } \\
\text { violence against } \\
\text { unmarried } \\
\text { female } \\
\text { adolescents }\end{array}$ & Bangladesh & $\begin{array}{l}4370 \\
\text { (unmarried } \\
\text { female } \\
\text { adolescents } \\
\text { aged 10-19) }\end{array}$ & Physical & Multiple & Multiple & $\begin{array}{l}\text { 'These findings highlight } \\
\text { the importance of } \\
\text { community context, } \\
\text { particularly community } \\
\text { norms accepting } \\
\text { violence, in regards to } \\
\text { physical violence against } \\
\text { women and girls, and } \\
\text { also have implications }\end{array}$ \\
\hline
\end{tabular}


Table 2 (continued)

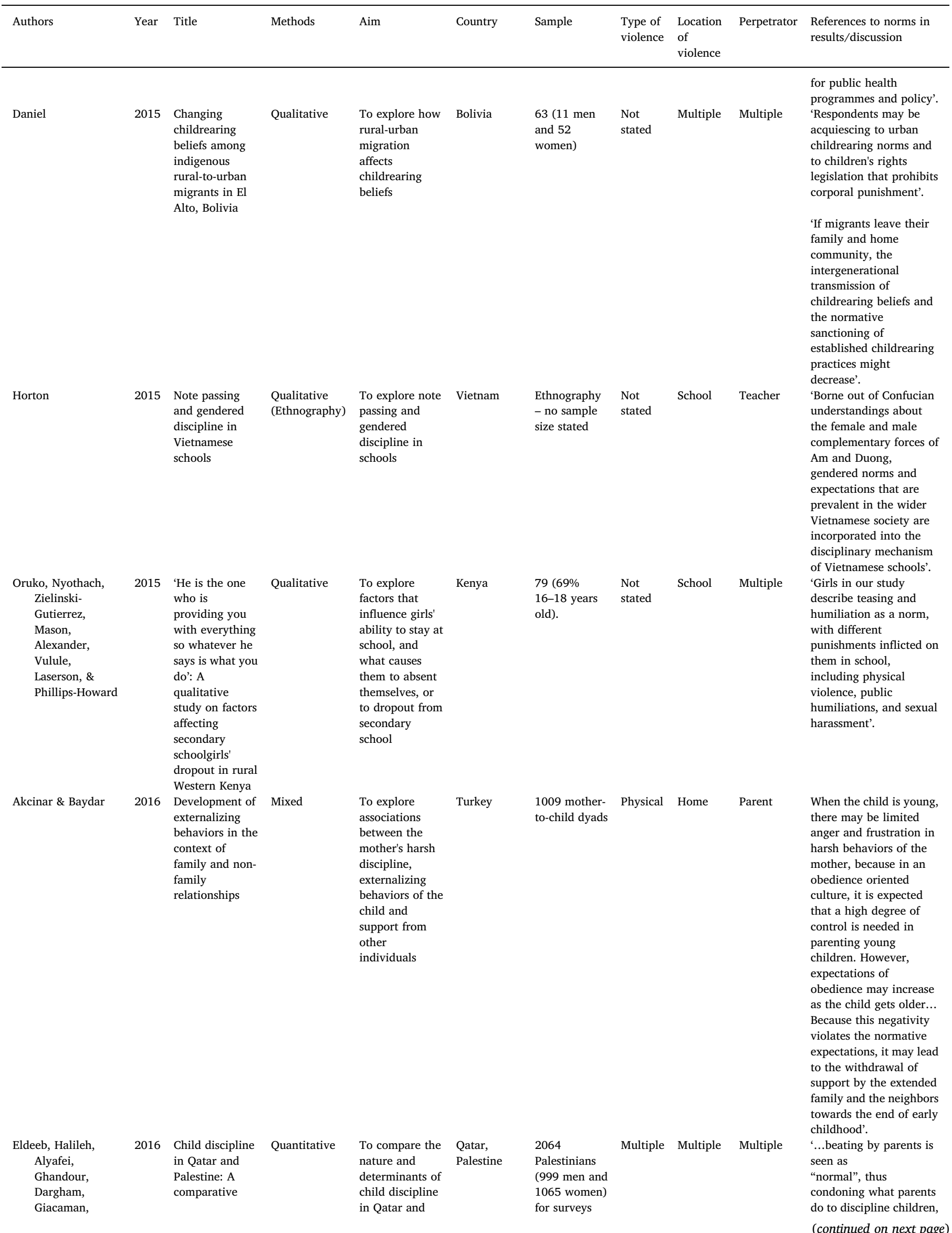


Table 2 (continued)

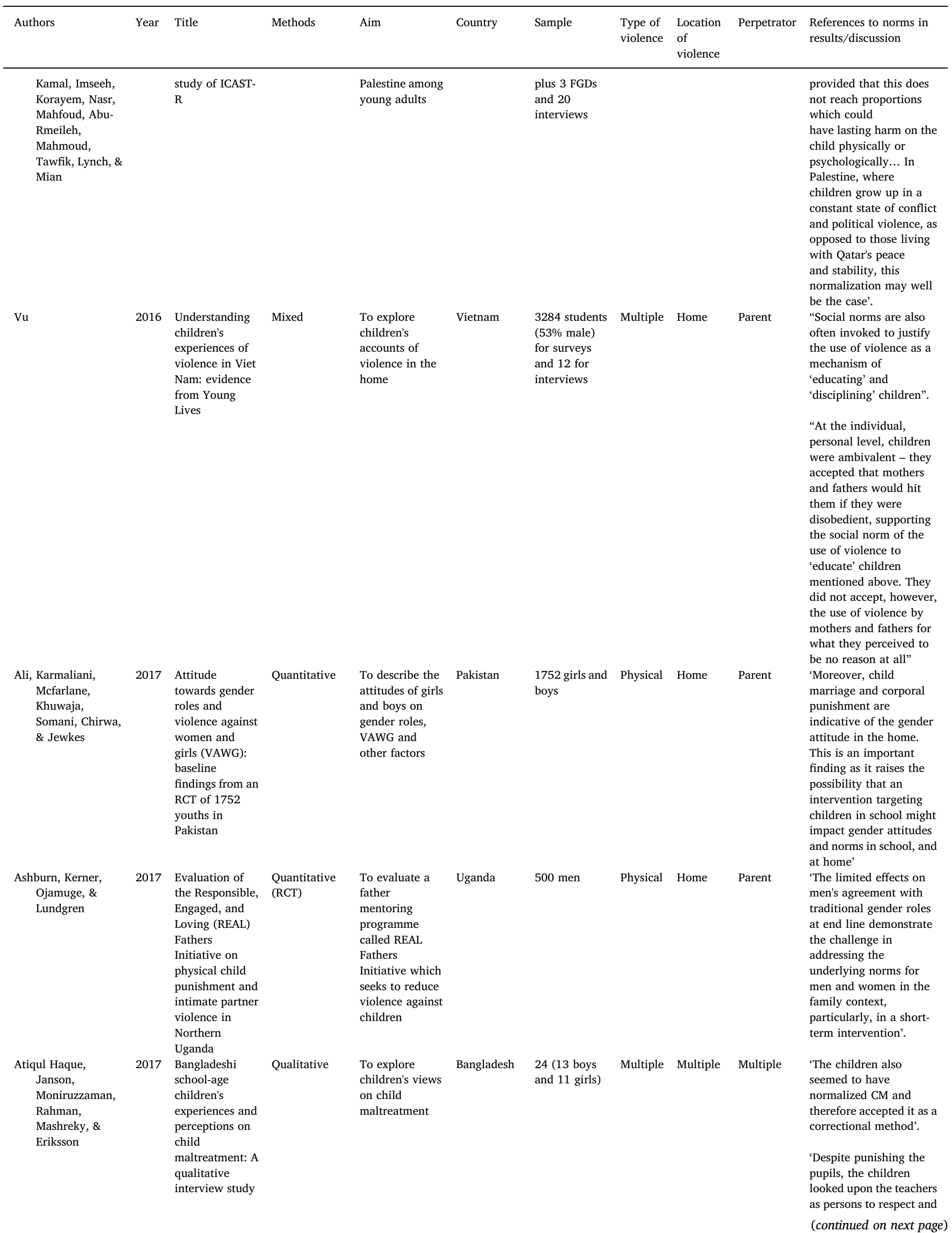


Table 2 (continued)

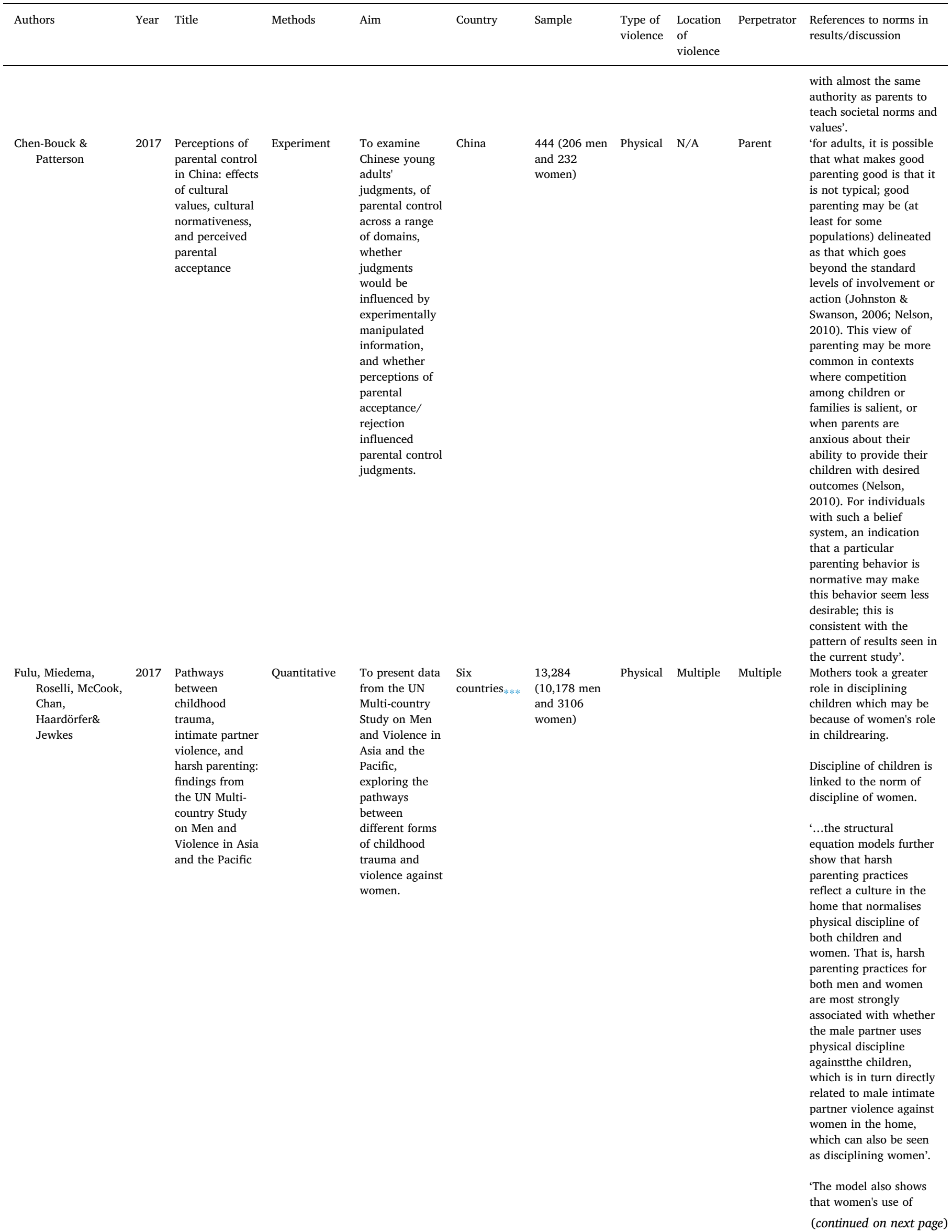


Table 2 (continued)

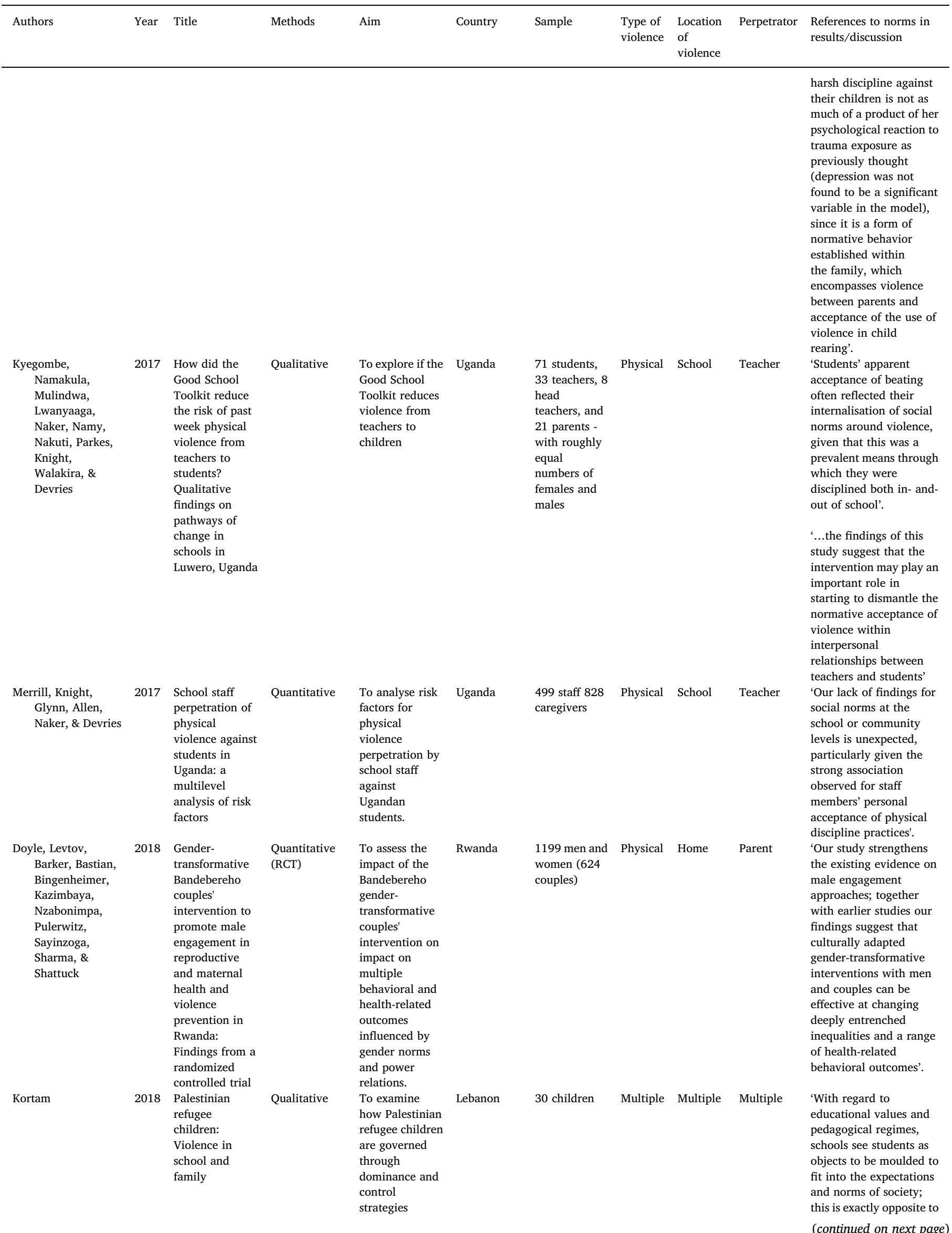


Table 2 (continued)

\begin{tabular}{|c|c|c|c|c|c|c|c|c|c|c|}
\hline Authors & Year & Title & Methods & Aim & Country & Sample & $\begin{array}{l}\text { Type of } \\
\text { violence }\end{array}$ & $\begin{array}{l}\text { Location } \\
\text { of } \\
\text { violence }\end{array}$ & Perpetrator & $\begin{array}{l}\text { References to norms in } \\
\text { results/discussion }\end{array}$ \\
\hline Liu \& Wang & 2018 & $\begin{array}{l}\text { Parental harsh } \\
\text { discipline and } \\
\text { adolescent } \\
\text { problem } \\
\text { behavior in } \\
\text { China: } \\
\text { perceived } \\
\text { normativeness } \\
\text { as a moderator }\end{array}$ & Quantitative & $\begin{array}{l}\text { To explore the } \\
\text { relationship } \\
\text { between harsh } \\
\text { discipline and } \\
\text { adolescent } \\
\text { problem } \\
\text { behaviors, as } \\
\text { well as how } \\
\text { normativeness } \\
\text { of harsh } \\
\text { discipline } \\
\text { affects this } \\
\text { relationship }\end{array}$ & China & $\begin{array}{l}1158(48.70 \% \\
\text { boys and } \\
51.3 \% \text { girls) }\end{array}$ & Physical & Home & Teacher & $\begin{array}{l}\text { schools' obligations to } \\
\text { meet the children's } \\
\text { intrinsic needs'. } \\
\text { '...the findings partially } \\
\text { supported the hypothesis } \\
\text { that the association } \\
\text { between parental harsh } \\
\text { discipline and } \\
\text { adolescents' problem } \\
\text { behavior was moderated } \\
\text { by the adolescents' } \\
\text { perceived normativeness } \\
\text { of harsh discipline. } \\
\text { However, the analyses } \\
\text { revealed that the } \\
\text { moderation was } \\
\text { contingent upon the type } \\
\text { of harsh discipline as } \\
\text { well as the type of } \\
\text { problem behavior } \\
\text { measured'. }\end{array}$ \\
\hline \multirow[t]{2}{*}{ Mayisela } & 2018 & $\begin{array}{l}\text { "Malicious to } \\
\text { the skin". The } \\
\text { internalisation } \\
\text { of corporal } \\
\text { punishment as a } \\
\text { teaching and a } \\
\text { disciplinary tool } \\
\text { among South } \\
\text { African teachers }\end{array}$ & $\begin{array}{l}\text { Qualitative } \\
\text { (Ethnography) }\end{array}$ & $\begin{array}{l}\text { To explore why } \\
\text { teachers still } \\
\text { use or believe in } \\
\text { corporal } \\
\text { punishment as a } \\
\text { disciplinary tool }\end{array}$ & South Africa & $\begin{array}{l}26(4 \text { men } \\
\text { and } 22 \\
\text { women) }\end{array}$ & Physical & School & Teacher & $\begin{array}{l}\text { '...this teacher may have } \\
\text { internalized the image } \\
\text { and power of the } \\
\text { teachers who physically } \\
\text { punished her, and her } \\
\text { own childhood fear, so } \\
\text { much so that it } \\
\text { eventually became } \\
\text { normal, as this form of } \\
\text { perpetration was long } \\
\text { term and socially } \\
\text { entrenched'. }\end{array}$ \\
\hline & & & & & & & & & & $\begin{array}{l}\text { 'This study further } \\
\text { proposes that the } \\
\text { normalized childhood } \\
\text { corporal punishment } \\
\text { exposure may be linked } \\
\text { to desensitisation of } \\
\text { empathy for goal- } \\
\text { oriented infliction of } \\
\text { physical pain on } \\
\text { children, as indicated by } \\
\text { sporadic laughter by } \\
\text { teachers in this study } \\
\text { when relating their } \\
\text { experiences and self- } \\
\text { identification with } \\
\text { corporal punishment'. }\end{array}$ \\
\hline $\begin{array}{l}\text { Merrill, Knight, } \\
\text { Namy, Allen, } \\
\text { Naker, \& Devries }\end{array}$ & 2018 & $\begin{array}{l}\text { Effects of a } \\
\text { violence } \\
\text { prevention } \\
\text { intervention in } \\
\text { schools and } \\
\text { surrounding } \\
\text { communities: } \\
\text { Secondary } \\
\text { analysis of a } \\
\text { cluster } \\
\text { randomized- } \\
\text { controlled trial } \\
\text { in Uganda }\end{array}$ & $\begin{array}{l}\text { Quantitative } \\
\text { (RCT) }\end{array}$ & $\begin{array}{l}\text { To investigate } \\
\text { intervention } \\
\text { effects on } \\
\text { school } \\
\text { operational } \\
\text { culture, and on } \\
\text { normative } \\
\text { beliefs and } \\
\text { violence against } \\
\text { children from } \\
\text { caregivers } \\
\text { outside of } \\
\text { school }\end{array}$ & Uganda & $\begin{array}{l}3820 \\
\text { children, } 597 \\
\text { school staff } \\
\text { and } 799 \\
\text { caregivers }\end{array}$ & Multiple & Multiple & Multiple & $\begin{array}{l}\text { 'Outside of the school } \\
\text { setting, differences were } \\
\text { observed in normative } \\
\text { beliefs in communities } \\
\text { surrounding control and } \\
\text { intervention schools...' }\end{array}$ \\
\hline $\begin{array}{l}\text { Stark, Seff, Asghar, } \\
\text { Roth, Bakamore, } \\
\text { MacRae, } \\
\text { D'Andon, \& Falb }\end{array}$ & 2018 & $\begin{array}{l}\text { Building } \\
\text { caregivers' } \\
\text { emotional, } \\
\text { parental and } \\
\text { social support } \\
\text { skills to prevent } \\
\text { violence against } \\
\text { adolescent girls: } \\
\text { findings from a } \\
\text { cluster }\end{array}$ & $\begin{array}{l}\text { Quantitative } \\
\text { (RCT) }\end{array}$ & $\begin{array}{l}\text { To present } \\
\text { results from a } \\
\text { cluster } \\
\text { randomized } \\
\text { controlled trial } \\
\text { to assess the } \\
\text { added impact of } \\
\text { the COMPASS } \\
\text { caregiver } \\
\text { curriculum to }\end{array}$ & DRC & $\begin{array}{l}869 \\
\text { adolescent } \\
\text { girls aged } \\
10-14 \\
\text { and } 764 \\
\text { caregivers }\end{array}$ & Physical & Home & Parent & $\begin{array}{l}\text { 'Caregivers who } \\
\text { participated in the } \\
\text { intervention did not } \\
\text { exhibit statistically } \\
\text { significant differences in } \\
\text { attitudes towards gender } \\
\text { inequitable norms or } \\
\text { acceptance of physical } \\
\text { discipline for children...' }\end{array}$ \\
\hline
\end{tabular}


Table 2 (continued)

\begin{tabular}{|c|c|c|c|c|c|c|c|c|c|c|}
\hline Authors & Year & Title & Methods & Aim & Country & Sample & $\begin{array}{l}\text { Type of } \\
\text { violence }\end{array}$ & $\begin{array}{l}\text { Location } \\
\text { of } \\
\text { violence }\end{array}$ & Perpetrator & $\begin{array}{l}\text { References to norms in } \\
\text { results/discussion }\end{array}$ \\
\hline & & $\begin{array}{l}\text { randomized } \\
\text { controlled trial } \\
\text { in Democratic } \\
\text { Republic of } \\
\text { Congo }\end{array}$ & & $\begin{array}{l}\text { the girls' } \\
\text { curriculum on } \\
\text { adolescent girls' } \\
\text { exposure to } \\
\text { sexual and } \\
\text { other forms of } \\
\text { violence, and } \\
\text { caregivers' } \\
\text { gender attitudes } \\
\text { and parenting } \\
\text { behaviors, } \\
\text { compared with } \\
\text { the COMPASS } \\
\text { girls' } \\
\text { programming } \\
\text { alone. }\end{array}$ & & & & & & $\begin{array}{l}\text { 'While caregivers may be } \\
\text { influential in setting } \\
\text { normative standards of } \\
\text { behavior for adolescents, } \\
\text { caregivers are } \\
\text { themselves influenced } \\
\text { by social norms, which } \\
\text { may set gendered } \\
\text { parameters on individual } \\
\text { authority within both } \\
\text { the household and the } \\
\text { community'. }\end{array}$ \\
\hline $\begin{array}{l}\text { Bjarnegård, } \\
\text { Brounéus, \& } \\
\text { Melander }\end{array}$ & 2019 & $\begin{array}{l}\text { Violent } \\
\text { boyhoods, } \\
\text { masculine } \\
\text { honor ideology, } \\
\text { and political } \\
\text { violence: survey } \\
\text { findings from } \\
\text { Thailand }\end{array}$ & 更 & $\begin{array}{l}\text { To explore how } \\
\text { experience of } \\
\text { violence during } \\
\text { childhood is } \\
\text { linked to adult } \\
\text { participation in } \\
\text { political } \\
\text { violence }\end{array}$ & 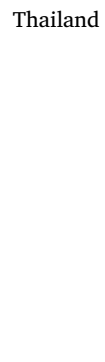 & 200 men & $\begin{array}{l}\text { Not } \\
\text { stated }\end{array}$ & Multiple & Multiple & $\begin{array}{l}\text { 'Family-of-origin } \\
\text { violence may lead to an } \\
\text { increased risk of } \\
\text { participating in political } \\
\text { violence due to the } \\
\text { diffusion of masculine } \\
\text { honor ideology and } \\
\text { violence norms, whereby } \\
\text { violence is seen as a just, } \\
\text { appropriate, and } \\
\text { masculine response to } \\
\text { conflict'. }\end{array}$ \\
\hline $\begin{array}{l}\text { Lundgren, Burgess, } \\
\text { Chantelois, } \\
\text { Oregede, Kerner, } \\
\text { \& Kågesten }\end{array}$ & 2019 & $\begin{array}{l}\text { Processing } \\
\text { gender: lived } \\
\text { experiences of } \\
\text { reproducing and } \\
\text { transforming } \\
\text { gender norms } \\
\text { over the life } \\
\text { course of young } \\
\text { people in } \\
\text { Northern } \\
\text { Uganda }\end{array}$ & Ethnography & $\begin{array}{l}\text { To understand } \\
\text { how gendered } \\
\text { norms and } \\
\text { practices } \\
\text { develop during } \\
\text { the transition } \\
\text { from child to } \\
\text { young adult in } \\
\text { post-conflict } \\
\text { northern } \\
\text { Uganda. }\end{array}$ & Uganda & $\begin{array}{l}47 \text { ( } 25 \text { boys } \\
\text { and } 22 \text { girls) }\end{array}$ & $\begin{array}{l}\text { Not } \\
\text { stated }\end{array}$ & Home & Relative & $\begin{array}{l}\text { 'Throughout the course } \\
\text { of adolescent } \\
\text { development, the study } \\
\text { participants engaged } \\
\text { with gender norms } \\
\text { through a series of } \\
\text { socialization processes } \\
\text { including role } \\
\text { modelling, mentoring, } \\
\text { instruction, task } \\
\text { assignment and } \\
\text { discipline. As } \\
\text { participants assumed } \\
\text { new roles and } \\
\text { responsibilities, they } \\
\text { learned both patriarchal } \\
\text { and alternative norms by } \\
\text { observing and receiving } \\
\text { (or not) advice from } \\
\text { their social networks } \\
\text { (e.g. parents, peers, in- } \\
\text { laws, spouses)'. }\end{array}$ \\
\hline
\end{tabular}

* Albania, Algeria, Azerbaijan, Belarus, Belize, Bosnia and Herzegovina, Burkina Faso, Cameroon, Central African Republic, Côte d'Ivoire, Djibouti, Egypt, Gambia, Georgia, Ghana, Guinea-Bissau, Guyana, Iraq, Jamaica, Kazakhstan, Kyrgyzstan, Lao PDR, Mongolia, Montenegro, Serbia, Sierra Leone, Suriname, Syrian Arab Republic, Tajikistan, The former Yugoslav Republic of Macedonia, Togo, Trinidad and Tobago, Ukraine, Vietnam, Yemen.

** Albania, Belize, Bosnia and Herzegovina, Burkina Faso, Côte d'Ivoire, Gambia, Georgia, Ghana, Guinea-Bissau, Guyana, Iraq, Jamaica, Kazakhstan, Kyrgyzstan, Lao PDR, Montenegro, Serbia, Sierra Leone, Suriname, Tajikistan, Togo, Trinidad and Tobago, Ukraine, Vietnam.

*** Bangladesh, Cambodia, China, Indonesia, Papua New Guinea, Sri Lanka. 
total, 13 (35\%) studies position the focus of the study as exploring the causes of violence; 7 (19\%) on demonstrating prevalence, scope or severity; $5(14 \%)$ on testing an intervention; $5(14 \%)$ on exploring the causes and consequences of violence; $4(10 \%)$ on consequences only; and the remaining $3(8 \%)$ focused on multiple or other dimensions.

\subsubsection{Definitions and measures of social norms}

Overall, 16 (43\%) of the 37 studies referenced some kind of theory on norms ( 1 of these does not mention norms in the results or discussion), while 21 (57\%) provided results or discussion on norms without any theoretical framing, and 14 studies provide both theoretical content as well as empirical content on norms within the results or discussion. Three studies included a definition of norms (Lundgren et al., 2019; Merrill et al., 2017; International Center for Research on Women and Plan International, 2014), while others used social learning and role theories to refer to norms (Ashburn, Kerner, Ojamuge, \& Lundgren, 2017; Bjarnegård, Brounéus, \& Melander, 2019; Wilson, Wilson, \& Fox, 2002). Two studies referred to perceived and actual normativity (ChenBouck \& Patterson, 2017; Lansford et al., 2005).

\subsection{Social and gender norms sustaining corporal punishment}

We now turn to findings from the studies included on the normative elements of CPD. Of the 37 included studies, 34 found that norms are relevant for understanding why parents and/or teachers adopt CPD as a discipline strategy and the remaining 3 studies show that there are cases where norms do not sustain CPD. Among the studies that found links between norms and CPD, three themes specifically emerged from our analysis of the studies, informed by our research questions: 1) Norms both sustain and limit CPD; 2) Gender norms sustain the uses of CPD and shape children's experiences; 3) Conflict, migration and modernization influence norms sustaining CPD.

\subsubsection{Norms can both sustain and limit CPD}

A group of studies found CPD to be sustained by normative beliefs that CPD was both typical and appropriate in participants' contexts (Akcinar \& Baydar, 2016; Atiqul Haque et al., 2017; Humphreys, 2008; Kortam, 2018; Lansford et al., 2005; J.E. Lansford, Deater-Deckard, Bornstein, Putnick, \& Bradley, 2014; Nutter, 2013; Twum-Danso, 2010; $\mathrm{Vu}, 2016)$. A few specifically looked at the dynamics through which CPD becomes socially acceptable and normalized. Lansford et al.'s (2014) study in 25 countries, suggested that CPD becomes acceptable when it is embedded in an overarching societal context supportive of violence. Their results resonate with Humphreys (2008) study in Botswana, which found that CPD can become normalized through the routine and trivial use of violence. Similarly, Mayisela's (2018) study in South Africa found that teachers' own experiences of violent discipline within hierarchical school structures desensitized them to violence and perpetuated their normalization of CPD. Nutter's (2013) study in Morocco found that the lack of protection and care of authority figures during childhood resulted in excessive CPD, while Fulu et al. (2017) in their multi-country study situate CPD within the normalization of physical violence towards women.

Parents and teachers were influenced by the norms which supported CPD, leading them to use violence in the home and school. Wilson et al.'s (2002) study in Guyana found that parents learn their behavior from watching what others do, and in South Africa, Dawes, De Sas Kropiwnicki, Kafaar, and Richter (2005) explained how the scripts for parenting are provided by the socio-cultural context. The effect of these scripts varies across age and gender (gender will be discussed in detail below). For example, Akcinar and Baydar (2016) study in Turkey found that young children were expected to need greater guidance, so parents were more tolerant and less likely to use CPD with them, as compared to older children. In India, Morrow and Singh (2014) also found that CPD was seen as appropriate for younger children, but not for older children.
Some studies also focused on how the same norms of acceptability of CPD among parents extended to the school, such that children assigned to teachers the same authority they recognized in parents (Archambault, 2009; Atiqul Haque et al., 2017; Kyegombe et al., 2017). For instance, Kyegombe et al.'s (2017) study in Uganda suggested: "teachers are seen to act in loco parentis and discipline a child just as a parent would had they been present, thus continuing a cycle of similar punishment as may have occurred at home" (p. 17). In Nutter's (2013) study in Morocco, hitting was considered a socially appropriate way of caring for children, and caring was considered a responsibility of both family members (at home) and the state (at school). Teachers, who were seen by parents as part of the state apparatus, were expected to care for students by hitting them when they deserved it.

Importantly, a few studies highlighted that the norm of CPD has limits, both for children and adults; that is, that they would consider CPD socially acceptable only up to a certain level of severity. Atiqul Haque et al.'s (2017) study in Bangladesh, for instance, found that, while children internalize CPD as an acceptable form of discipline, inconsistency or randomness of punishment increases their ambivalence towards it. In Vietnam, Vu (2016) reported that children felt that, CPD is only acceptable, if it occurs for certain reasons. Adults also identified limits to socially acceptable CPD. For instance, Eldeeb et al.'s (2016) study in Palestine, young adults acknowledged that CPD required a good reason to be acceptable. Participants in other studies contended that when CPD is too frequent or too prolonged, other adults would either intervene to stop it (Nutter, 2013; Twum-Danso, 2010) or, at the very least, disapprove of parents using it (Akcinar \& Baydar, 2016). The existence of a social threshold of acceptability for CPD was sometimes protective. In Nutter's (2013) ethnographic study in Morocco, participants expressed concern when CPD occurred in private, because other adults could not intervene. In contrast, Kortam's (2018) research in Lebanon found that participants ostracized parents who publicly punished their children, suggesting the existence of a norm against CPD.

\subsubsection{Gender norms affect how boys and girls experience CPD}

Gender norms assigning roles of caregivers to women meant mothers more often used CPD to discipline their children (Dawes et al., 2005; Doyle et al., 2018; Fulu et al., 2017). Dawes et al.'s (2005) study in South Africa suggested that despite mothers using CPD more often than fathers, fathers were more likely to approve of CPD. In addition to influencing who carries out CPD in the household, gender norms regulate which forms of CPD are considered acceptable for teachers to use: in Kenya, Archambault (2009) found that male teachers were reluctant to cane female students and female teachers would only cane younger (not older) boys.

Children's experience of CPD can also be influenced by gender norms. A few studies suggest that boys experience higher severity and frequency of physical punishment (Dawes et al., 2005; Minturn, Boyd, \& Kapoor, 1978; Morrow \& Singh, 2014; Wilson et al., 2002). In Vietnam, however, Horton (2015) found that girls experienced CPD more frequently than boys at school because they were generally seen as well-behaved, leading to any misdemeanours being viewed more seriously. Finally, in Lesotho, gendered power relations and norms intersected with teachers' authority: male teachers hit girls and lowered their marks as punishment for rejecting sexual relations with them (Ngakane, Muthukrishna, \& Ngcobo, 2012).

\subsubsection{Conflict, migration and modernization influence norms sustaining} $C P D$

Some studies provided evidence that the normative acceptability of CPD can also be influenced by contextual macro-factors like conflict, migration, and modernization. Eldeeb et al.'s (2016) study in Palestine found that the ongoing conflict normalized CPD. Mayisela's (2018) study in South Africa found that the historical context of structural violence in the country induced cultural acceptability of violence that contributed to making CPD socially acceptable. In Bolivia, Daniel 
(2015) observed that migration resulted in changes in how parents punished children, as long as parents were exposed to different parenting models in these new contexts. In Ghana, Twum-Danso (2010) noted that migration from rural to urban areas led to parents being influenced by different approaches to childrearing. In India, a longitudinal study by Minturn et al. (1978) found that modernization (including increased education of women) increased mothers' power, resulting in them experiencing greater autonomy, increased mobility, and more confidence in the presence of their mothers-in-law. These changes in women's position in the household led to them disciplining their children more firmly. In Kenya, Archambault (2009) found that the modern and traditional intersected to perpetuate CPD. Her study among the Maasai highlighted how punishment was grounded both in traditional ideas of childhood but was emerged from modern notions of personhood. In Vietnam, Horton (2015) found that traditional cultural Confucianist ideologies persisted, holding in place norms on child punishment.

\subsubsection{Evidence of social norms not linked to $C P D$}

Although the majority of the studies align with the three broad themes presented above, 3 studies provided contrasting evidence to show that there were cases where norms did not sustain CPD. The study by Chen-Bouck and Patterson (2017) in China found that the normative acceptability of CPD did not affect its use. In their study in Uganda, Merrill et al. (2017) could not find an association between norms and $\mathrm{CPD}$, but rather than concluding that association was inexistent, they suggested that it might be difficult to measure quantitatively. At times the relevance of norms may be contradictory. In their multi-country study, UNICEF (2010) reported that children were more likely to experience CPD when the primary caregiver approved of it. However, the same study showed that the opposite was not always true: despite some parents holding attitudes against CPD, they still practiced CPD.

\subsubsection{Interventions addressing social and gender norms that sustain corporal punishment}

We found only five studies that evaluated interventions on CPD and norms. These interventions aimed at changing: 1) social norms (Ashburn et al., 2017; Doyle et al., 2018; Merrill et al., 2018), 2) personal attitudes (Ashburn et al., 2017; Stark et al., 2018), and 3) CPDrelated practices of parents and teachers (Ashburn et al., 2017; Kyegombe et al., 2017). Table 3 outlines the aims of these studies as well as the interventions they evaluated.

Efforts to change norms were included within multi-component interventions, making it challenging to isolate the effects of norm change. The specific norm change components in these studies include: 1) use of a parenting curriculum (especially the promotion of "positive parenting" and non-violent discipline methods) (Ashburn et al., 2017), 2) facilitated sessions enabling reflection on gender norms and nonviolence (Doyle et al., 2018;Kyegombe et al., 2017; Merrill et al., 2018), 3) improving the school environment including governance structures (Kyegombe et al., 2017; Merrill et al., 2018), 4) targeting relationships between teachers, students, peers, parents and the community (Kyegombe et al., 2017; Merrill et al., 2018; Stark et al., 2018), and 5) improving the social assets and life skills of girls (Stark et al., 2018). In these studies, norms were positioned as a means of reducing CPD, however, were not the focus of intervention studies.

We now turn to the results of intervention studies that are related to changes in norms, attitudes and behaviors. In each of the five studies, the role that norms play in reducing CPD is not always straightforward, often because of a lack of clarity on how attitude and behavior change translates to norm change (Ashburn et al., 2017; Doyle et al., 2018). For example, in Doyle et al.'s (2018) study in Rwanda, norms were only theorized, but the results, discussion or conclusion did not refer to norms and instead only focused on behavior change. In other studies, norms were theorized and analyzed in the results, but the studies concluded that only behaviors or attitudes changed as a result of the

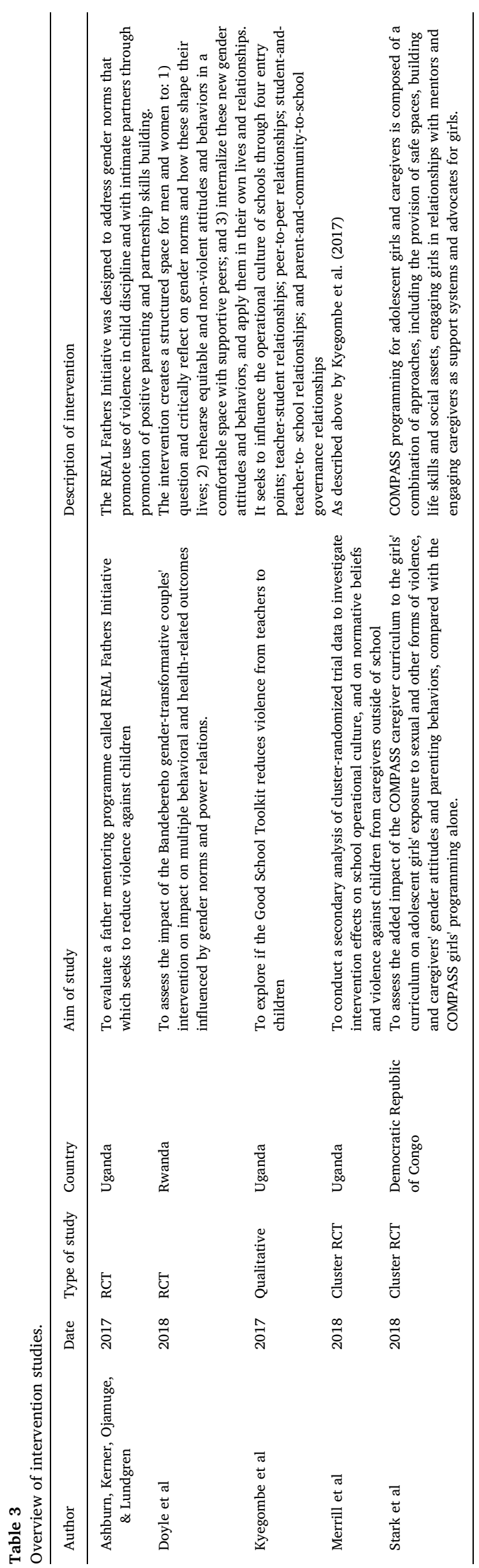


interventions, but norms did not. For example, in an evaluation of the REAL Fathers initiative in Uganda, Ashburn et al. (2017) note that the intervention had no effect on gender norms, however they documented changes in attitudes on CPD at the end of the intervention. Importantly, actual use of CPD only decreased at long-term follow-up, suggesting that norm-related violent practices can take longer than the intervention lifespan to change. Stark et al. (2018) came to a similar conclusion studying the COMPASS intervention in the Democratic Republic of Congo, noting that COMPASS did not result in statistically significant changes in acceptance of CPD. The authors suggested that the norms sustaining CPD would take longer or require higher doses of intervention than the monthly discussion sessions offered by COMPASS. However, the intervention did result in caregivers showing more affection and warmth to their children.

Other studies reveal more mixed findings. In a qualitative evaluation of the Good Schools Toolkit in Uganda, Kyegombe et al. (2017) found that, by challenging old norms and introducing new norms, the intervention helped teachers to abandon the use of CPD and adopt a reward and praisebased educative approach. However, some teachers (especially those working in rural government schools) reported that some pupil behavior worsened as a result of the intervention, as children now knew they could not be subject to CPD. Some parents viewed the intervention negatively: parents' attitudes towards CPD had not changed, they still practiced CPD and considered teachers that did not use it as incapable, with some eventually moving their children to schools that still practiced CPD. The authors note the discrepancy between changes in school disciplinary practices and the continuation of violent discipline at home. In a subsequent RCT study of the same intervention, however, Merrill et al. (2018) found that Good School Toolkit reduced acceptance of physical discipline at school and suggested that these positive results had a spill-over effect beyond the school setting.

\section{Discussion}

This review included 37 studies conducted with data from 59 countries which examined links between social norms and CPD in LMICs. Most of these studies defined physical violence as the primary outcome, examined the causes of CPD, and identified both parents and teachers as perpetrators. Many studies demonstrated links between social or gender norms and CPD, and several studies showed how contextual changes (conflict, migration and modernization) served to reduce or increase support for CPD perpetration.

Our review shows there is a growing recognition of the way social norms influence punishment and discipline of children: most studies were published between 2010 and 2019 and all the intervention studies were published after 2017. However, we find gaps remain in the use of norms theory to map, measure and evaluate the links between norms and CPD. For example, in over half the studies, the language of norms is often used without a conceptual framework, sometimes conflating norms with other constructs (attitudes, beliefs, behaviors). In particular, the intervention studies assume linkages between attitudes, behaviors and norms which are not explicitly mapped out or defined. Further, because norms were nearly never the main focus of studies, it is difficult to establish with certainty the ways through which norms affect CPD - which points to the need for more conceptually-grounded research that positions norms more strongly as the focus of research.

Despite gaps in data and definitions, our findings provide insights on the different normative contexts in which CPD can take place. Firstly, in contexts where there is a strong norm in support of CPD, we show parents and teachers practice CPD because the violence associated with CPD is normalized, and parents think it is expected of them. This highlights the importance of interventions to change the social and gender norms that normalize violence. However, our findings also show that social norms can both be harmful or protective. For example, even in contexts where there are norms which support CPD, in Ghana (Nutter, 2013) and Morocco (Twum-Danso, 2010) adult participants said they would intervene if they witnessed excessive punishment, and children in Palestine and Vietnam found CPD acceptable only in certain circumstances (Eldeeb et al., 2016; Vu, 2016). This may mean there are opportunities to leverage the "protective norm" around the limits of CPD, to bring broader social change (Cislaghi \& Heise, 2018b). Interventions focused on the "limits" of punishment, for example, may provide a useful entry-point for engagement before exploring harms of punishment more generally with communities.

Secondly, a small sample of studies provide examples of contexts where no norm is associated with CPD or where the norm does not have power. In these contexts, the individual attitudes of parents may be more relevant (UNICEF, 2010) and normative acceptability may not be linked to the practice of CPD (Chen-Bouck \& Patterson, 2017; Merrill et al., 2017). This accentuates the need for further research, to understand the influence or lack of influence of norms.

Thirdly, our findings underscore the importance of considering how gender, age, power hierarchies and contextual changes such as conflict, migration and modernization interact with and modify social and gender norms, opening pathways and possibilities of social change in either direction (i.e. with protective or harmful consequences) (Mayisela, 2018; Eldeeb et al., 2016; Daniel, 2015; Twum-Danso, 2010; Archambault, 2009; Minturn et al., 1978). These findings emphasize the importance of studying, and engaging with power hierarchies to understand how categories of social discrimination, such as gender, age, class, and experiences of conflict and migration affect acceptability of CPD norms. It also emphasizes the importance of localized interventions rather than replication of similar responses to CPD in every context.

In addition to the links between normative contexts and CPD, this review included five intervention studies conducted in Democratic Republic of Congo, Rwanda and Uganda, which integrated norm change into multi-component interventions. Findings from our analyses of these studies could be instructive in the design of interventions to change social and gender norms that sustain CPD. For example, we observed that school-based interventions have potential to transform harmful norms sustaining CPD (Merrill et al., 2018) and bring about new positive education norms (Kyegombe et al., 2017). However, work by Kyegombe et al. (2017) highlight the risks of working with teachers and not parents, potentially changing norms among the former but not the latter. Other evidence suggests that working with both parents (Doyle et al., 2018) and only with fathers reduced the use of family CPD (Ashburn et al., 2017). However, these studies did not examine the school context. CPD interventions that target norms must work with entire social networks. Interventions may need to be more carefully designed to reflect an understanding of the home-school continuum, so that changes that occur at school do not occur in a vacuum but are part of broader community and home change. Expanding intervention research on CPD outside the Africa region may also be a fruitful way of engaging with the complex contextual factors underlying CPD.

Findings from the intervention studies also suggest that the frequency of exposure matters, such that longer and more frequent exposure can help kickstart processes of longer-term norm change (Stark et al., 2018) and might only emerge well after the end of an intervention (Ashburn et al., 2017). Future evaluations should thus integrate post-intervention follow-up to provide more meaningful data on effectiveness of interventions.

Finally, our findings suggest three trajectories for future research on norms and CPD. The first relates to the importance of strengthening the conceptual understanding of both norms and CPD in future work. Despite using the language of norms to describe how CPD occurs, few studies included a definition of social norms, yet they all acknowledge that norms sustain CPD. We identify a clear path for future research going forward: creating data collection tools and conducting analyses informed by social norms theory will provide deeper understanding - beyond what is mentioned in this review - of how norms can affect CPD. Further, many studies in this review narrowly defined $\mathrm{CPD}$, looking at it in isolation from other 
forms of non-physical punishment. Future studies should expand the investigation of how CPD affects children's lives with research on how children experience other forms of CPD (such as threats, ignoring/isolation, humiliation, or restricting access to resources), including how these forms of CPD can affect their wellbeing.

The second trajectory relates to the importance of an intersectional understanding of how gender, age, and other power hierarchies affect social norms sustaining CPD. Future research should look at how social norms of CPD intersect with gender roles that assign caregiving duties to women (resulting in women being the more common perpetrators of CPD). Similarly, it is important to expand on the existing understanding of how norms that regulate the acceptability of CPD shift as children age. Research along this trajectory could look at how social norms are created and embodied by the state, parents and teachers, including in conflicting ways that expose children to contrasting normative narratives.

Finally, our work looked specifically at social norms and CPD in LMICs. Given that intervention studies come from three countries in sub-Saharan Africa, further work to test interventions is needed in other LMICs. We also observed a large amount of work on the acceptability of CPD in high-income countries: this body of literature could be analyzed to explore links between poverty, racism and religion and CPD.

\section{Limitations}

Key limitations arose as we searched the literature, specifically related to the many meanings of the word "discipline". Where possible, $\mathrm{MeSH}$ (subject heading) terms helped to narrow the articles retrieved, however MeSH terms were not effective in IBSS or Scopus. The academic database search was also limited by being unable to access articles despite searching six separate repositories and libraries as well as conducting more general internet searches. While academic databases tend to be less biased, we cannot guarantee that our searches on Google and Google scholar were as objective. Piasecki, Waligora, and Dranseika (2017) document the range of limitations of Google searches, including results being influenced by search history and location. The first author attempted to mitigate against these limitations by clearing browsing data after each search and not signing into Google. This, however, does not necessarily resolve the issue of results being influenced by location, which can only be resolved by using an IP blocker. Similar to the Google search, the systematic nature of the review was limited by the lack of transparency in how Google Scholar searches occur (Haddaway, Collins, Coughlin, \& Kirk, 2015). The search of institutional websites was also limited due to poor search functionality (Adams et al., 2017). Only a few of these websites had advanced search features. Some websites were only periodically updated or contained old/expired links. Many websites referenced documents that had since been removed from institutional websites. Our search strategy was also limited by only focusing on articles written in English. As described earlier, we ran supplementary searches which showed that 21 articles in French and Spanish would have been included in the full-text review if our review included these languages.

A key limitation during the screening of articles included the subjective nature of making decisions based on norms content, as reviewers may have viewed what was "substantive" norms content differently. However, we made efforts to mitigate this by cross-checking data during the screening and extraction process, and meeting regularly throughout the screening process. Given that we exclusively focused on articles that used the word 'norm', there were additional articles that examined adjacent terms that this review did not include.

Finally, the review was also constrained by the methodological limitations within included studies. Importantly, methodological diversity made comparison between studies challenging. We have not assessed quality of studies systematically. The lack of consistent reporting on biases, limitations and, where appropriate, reflexivity, affected the quality of analysis of included studies. Nearly all studies did not recognize the challenges of conducting research on $\mathrm{CPD}$, especially given recent changes in laws that may limit the willingness of parents and teachers to provide honest responses on their use of CPD. As noted by Merrill et al. (2018), a critical aspect that may affect the intervention studies is that communities may feel it is less acceptable to disclose ongoing use of violent discipline after receiving the intervention, so this may have affected the data. Other challenges affecting our review include lack of clarity on conclusions related to CPD, due to the fact that CPD was not the sole focus of over $50 \%$ of studies, rather was considered as one component of wider school- or home-based violence.

\section{Conclusion}

In this review, 37 studies from different cultural contexts, provide evidence that norms of acceptability matter in sustaining CPD against children. This systematic review highlights the importance of identifying whether a norm exists, and the roles multiple actors (teachers, parents, children) in a social network play in perpetrating or preventing CPD. The review emphasizes that even where harmful norms exist, limits to these norms may reduce the acceptability of some forms of punishment and discipline, which may be leveraged to restrict violent discipline. This review also draws attention to gender and age, as well as contextual changes like conflict, migration and modernization as critical elements for understanding CPD. It suggests that greater care needs to be taken in designing interventions, recognizing the continuum that exists between the home and school and acknowledging the complexities in bringing about norm change across multiple spheres.

\section{Funder}

This research was funded by an anonymous donor. The donor had no role in the analysis or write-up of this article.

\section{Appendix A. Supplementary data}

Supplementary data to this article can be found online at https:// doi.org/10.1016/j.avb.2020.101507.

\section{References}

Adams, R. J., Smart, P., \& Huff, A. S. (2017). Shades of grey: Guidelines for working with the grey literature in systematic reviews for management and organizational studies. International Journal of Management Reviews, 19, 432-454.

*Akcinar, B., \& Baydar, N. (2016). Development of externalizing behaviors in the context of family and non-family relationships. Journal of Child and Family Studies, 25(6), 1848-1859.

*Archambault, C. (2009). Pain with punishment and the negotiation of childhood: An ethnographic analysis of children's rights process in Maasailand. Africa, 79(2), 282-302.

"Ashburn, K., Kerner, B., Ojamuge, D., \& Lundgren, R. (2017). Evaluation of the responsible, engaged, and loving (REAL) fathers initiative on physical child punishment and intimate partner violence in northern Uganda. Prevention Science, 18(7), 854-864.

*Atiqul Haque, M., Janson, S., Moniruzzaman, S., Rahman, A. K. M. F., Mashreky, S. R., \& Eriksson, U. B. (2017). Bangladeshi school-age children's experiences and perceptions on child maltreatment: A qualitative interview study. Child: Care, Health \& Development, 43(6), 876-883.

Bicchieri, C. (2006). The grammar of society: The nature and dynamics of social norms. New York: Cambridge University Press.

*Bjarnegård, E., Brounéus, K., \& Melander, E. (2019). Violent boyhoods, masculine honor ideology, and political violence: Survey findings from Thailand. Journal of Interpersonal Violence, 1-25.

*Centers for Disease Control \& Prevention, Interuniversity Institute for Research and Development, \& Comité de Coordination (2014). Violence against children in Haiti: Findings from a national survey, Port-au-Prince, Haiti: Centers for Disease Control and Prevention.

*Chen-Bouck, L., \& Patterson, M. M. (2017). Perceptions of parental control in China: Effects of cultural values, cultural normativeness, and perceived parental acceptance. Journal of Family Issues, 38(9), 1288-1312.

Cialdini, R. B., Reno, R. R., \& Kallgren, C. A. (1990). A focus theory of normative conduct:

\footnotetext{
${ }^{1}$ References marked with an asterisk indicate studies included in the systematic review.
} 
Recycling the concept of norms to reduce littering in public places. Journal of Personality and Social Psychology, 58, 1015-1026.

Cislaghi, B., \& Heise, L. (2018a). Four avenues of normative influence: A research agenda for health promotion in low and mid-income countries. Health Psychology, 37(6), 562-573.

Cislaghi, B., \& Heise, L. (2018b). Theory and practice of social norms interventions: Eight common pitfalls. Globalization and Health, 14(83), 1-10.

Cislaghi, B., \& Heise, L. (2019). Using social norms theory for health promotion in lowincome countries. Health Promotion International, 34(3), 616-623.

"Daniel, C. (2015). Changing childrearing beliefs among indigenous rural-to-urban migrants in El Alto, Bolivia. Sociological Forum, 30(4), 949-970.

*Dawes, A., De Sas Kropiwnicki, Z., Kafaar, Z., \& Richter, L. (2005). Corporal punishment of children: A South African national survey. (Save the Children Sweden).

Dietz, T. L. (2000). Disciplining children: Characteristics associated with the use of corporal punishment. Child Abuse \& Neglect, 24(12), 1259-1542.

"Doyle, K., Levtov, R. G., Barker, G., Bastian, G. G., Bingenheimer, J. B., Kazimbaya, S., Nzabonimpa, A., Pulerwitz, J., Sayinzoga, F., Sharma, V., \& Shattuck, D. (2018). Gender-transformative Bandebereho couples' intervention to promote male engagement in reproductive and maternal health and violence prevention in Rwanda: Findings from a randomized controlled trial. PLoS One, 13(4), 1-17.

Eamon, M. K. (2001). Antecedents and socioemotional consequences of physical punishment on children in two-parent families. Child Abuse \& Neglect, 25(6), 787-802.

*Eldeeb, N., Halileh, S., Alyafei, K. A., Ghandour, R., Dargham, S., Giacaman, R., Kamal, M., Imseeh, S., Korayem, M., Nasr, S., Mahfoud, Z., Abu-Rmeileh, N., Mahmoud, M. H., Tawfik, H., Lynch, M. A., \& Mian, M. (2016). Child discipline in Qatar and Palestine: A comparative study of ICAST-R. Child Abuse \& Neglect, 61, 63-72.

Ferrari, A. M. (2002). The impact of culture upon child rearing practices and definitions of maltreatment. Child Abuse \& Neglect, 26(8), 793-813.

Fleckman, J. M., Taylor, C., Theall, K., \& Andrinopoulos, K. (2019). The association between perceived injunctive norms toward corporal punishment, parenting support, and risk for child physical abuse. Child Abuse \& Neglect, 88, 246-255.

*Fulu, E., Miedema, S., Roselli, T., McCook, S., Chan, K. L., Haardörfer, R., \& Jewkes, R. (2017). Pathways between childhood trauma, intimate partner violence, and harsh parenting: Findings from the UN multi-country study on men and violence in Asia and the Pacific. Lancet Global Health, 5, e512-e522.

Gershoff, E. T., \& Grogan-Kaylor, A. (2016). Spanking and child outcomes: Old controversies and new meta-analyses. Journal of Family Psychology, 30(4), 453-469.

Haddaway, N. R., Collins, A. M., Coughlin, D., \& Kirk, S. (2015). The role of Google scholar in evidence reviews and its applicability to grey literature searching. PLoS One, 10(9), 1-17.

"Horton, P. (2015). Note passing and gendered discipline in Vietnamese schools. British Journal of Sociology of Education, 36(4), 526-541.

*Humphreys, S. (2008). Gendering corporal punishment: Beyond the discourse of human rights. Gender \& Education, 20(5), 527-540.

*International Center for Research on Women \& Plan International (2014). Are schools safe and gender equal spaces? Findings from a baseline study of school related gender-based violence in five countries in Asia, International Center for Research on Women \& Plan International.

Kalamar, A. M., Lee-Rife, S., \& Hindin, M. J. (2016). Interventions to prevent child marriage among young people in low- and middle-income countries: A systematic review of the published and grey literature. Journal of Adolescent Health, 59(3), S16-S21.

*Kortam, M. (2018). Palestinian refugee children: Violence in school and family. International Sociology, 33(4), 486-502.

*Kyegombe, N., Namakula, S., Mulindwa, J., Lwanyaaga, J., Naker, D., Namy, S. Devries, K. M. (2017). How did the good school toolkit reduce the risk of past week physical violence from teachers to students? Qualitative findings on pathways of change in schools in Luwero, Uganda. Social Science \& Medicine, 180, 10-19.

*Lansford, J. E., Chang, L., Dodge, K. A., Malone, P. S., Oburu, P., Palmérus, K., ... Quinn, N. (2005). Physical discipline and children's adjustment: Cultural normativeness as a moderator. Child Development, 76(6), 1234-1246.

Lansford, J.E., Alampay, L.P., Al-Hassan, S., Bacchini, D., Bombi, A.S., Bornstein, M.H., Chang, L., Deater-Deckard, K., Di Giunta, L., Dodge, K., Oburu, P., Pastorelli, C, Runyan, D.K., Skinner, A.T., Sorbring, E., Tapanya, S., Uribe Tirado, L.M., \& Zelli, A. (2010). Corporal punishment of children in nine countries as a function of child gender and parent gender, International Journal of Pediatrics, 1-12.

"Lansford, J. E., Deater-Deckard, K., Bornstein, M. H., Putnick, D. L., \& Bradley, R. H. (2014). Attitudes justifying domestic violence predict endorsement of corporal punishment and physical and psychological aggression towards children: A study in 25 low- and middle-income countries. The Journal of Pediatrics, 164(5), 1208-1213.

Larzelere, R. (1996). A review of the outcomes of parental use of nonabusive or customary physical punishment. Pediatrics, 98(4), 824-828.

Lau, J. T., Kim, J. H., Tsui, H. Y., Cheung, A., Lau, M., \& Yu, A. (2005). The relationship between physical maltreatment and substance use among adolescents: A survey of 95,788 adolescents in Hong Kong. Journal of Adolescent Health, 37, 110-119.

Legros, S., \& Cislaghi, B. (2019). Mapping the social-norms literature: An overview of reviews. Perspectives on Psychological Science, 1-19.

Lilleston, P. S., Goldmann, L., Verma, R. K. \& McCleary-Sills, J. (2017). Understanding social norms and violence in childhood: Theoretical underpinnings and strategies for intervention. Psychology, Health \& Medicine, 22(1), 122-134.

"Liu, L., \& Wang, M. (2018). Parental harsh discipline and adolescent problem behavior in China: Perceived normativeness as a moderator. Child Abuse \& Neglect, 86, 1-9.

*Lundgren, R., Burgess, S., Chantelois, H., Oregede, S., Kerner, B., \& Kågesten, A. E. (2019). Processing gender: Lived experiences of reproducing and transforming gender norms over the life course of young people in northern Uganda. Culture, Health \& Sexuality, 21(4), 387-403.
Mackie, G. (1996). Ending footbinding and infibulation: A convention account. American Sociological Review, 61(6), 999-1017.

Mallett, R., Hagen-Zanker, J., Slater, R., \& Duvendack, M. (2012). The benefits and challenges of using systematic reviews in international development research. Journal of Development Effectiveness, 4(3), 445-455.

"Mayisela, S. (2018). 'Malicious to the skin'. The internalisation of corporal punishment as a teaching and a disciplinary tool among South African teachers. Mind, Culture, \& Activity, 25(4), 293-307.

Mehlhausen-Hassoen, D. (2019). Gender-specific differences in corporal punishment and children's perceptions of their mothers' and fathers' parenting. Journal of Interpersonal Violence, 1-24.

*Merrill, K. G., Knight, K., Glynn, J. R., Allen, E., Naker, D., \& Devries, K. M. (2017). School staff perpetration of physical violence against students in Uganda: A multilevel analysis of risk factors. BMJ Open, 7, 1-11.

*Merrill, K. G., Knight, L., Namy, S., Allen, E., Naker, D., \& Devries, K. M. (2018). Effects of a violence prevention intervention in schools and surrounding communities: Secondary analysis of a cluster randomized-controlled trial in Uganda. Child Abuse \& Neglect, 84, 182-195.

Minturn, L., Boyd, D., \& Kapoor, S. (1978). Increased maternal power status: Changes in socialization in a restudy of Raijut mothers of Khalapur, India. Journal of CrossCultural Psychology, 9(4), 483-498.

Moon, D.J., Damman, J.L., \& Romero, A. (2018). The effects of primary care-based parenting interventions on parenting and child behavioral outcomes: A systematic review, Trauma, Violence \& Abuse, 1-19.

*Morrow, V., \& Singh, R. (2014). Corporal punishment in schools in Andhra Pradesh, India: Children's and parents' views. London: Young Lives.

*Ngakane, M. V., Muthukrishna, N., \& Ngcobo, J. E. (2012). Experiencing violence in schools: Voices of learners in the Lesotho context. The Anthropologist, 14(1), 39-48.

*Nutter, C. (2013). Discipline and development: Negotiating childhood and authority in rural Morocco. University of Chicago: Unpublished PhD dissertation.

Piasecki, J., Waligora, M., \& Dranseika, V. (2017). Google search as an additional source in systematic reviews. Science \& Engineering Ethics, 24(2), 809-810.

Rimal, R. N., \& Lapinksi, M. K. (2015). A re-explication of social norms, ten years later. Communication Theory, 25(4), 393-409.

Rodriguez, C. M., \& Sutherland, D. (1999). Predictors of parents' physical disciplinary practices. Child Abuse \& Neglect, 23(7), 651-657.

*Stark, L., Seff, I., Asghar, K., Roth, D., Bakamore, T., MacRae, M., ... Falb, K. L. (2018). Building caregivers' emotional, parental and social support skills to prevent violence against adolescent girls: Findings from a cluster randomized controlled trial in Democratic Republic of Congo. BMJ Global Health, 3, 1-13.

Stith, S. M., Liu, T., Davies, L. C., Boykin, E. L., Alder, M. C., Harris, J. M., ... Dees, J. E. M. E. G. (2009). Risk factors in child maltreatment: A meta-analytic review of the literature. Aggression and Violent Behaviour, 14, 13-29.

Straus, M. A., \& Paschall, M. J. (2009). Corporal punishment by mothers and development of children's cognitive ability: A longitudinal study of two nationally representative age cohorts. Journal of Aggression, Maltreatment \& Trauma, 18(5), 459-483.

Straus, M. A., Sugarman, D. B., \& Giles-Sims, J. (1997). Spanking by parents and subsequent antisocial behavior of children. The Archives of Pediatrics \& Adolescent Medicine, 151(8), 761-767.

Straus, M. A., \& Yodanis, C. L. (1996). Corporal punishment in adolescence and physical assaults on spouses in later life: What accounts for the link? Journal of Marriage and Family, 58(4), 825-841.

Taylor, C. A., Hamvas, L., Rice, J., Newman, D. L., \& DeJong, W. (2011). Perceived social norms, expectations, and attitudes toward corporal punishment among an urban community sample of parents. Journal of Urban Health, 88(2), 254-269.

Turner, H. A., \& Muller, P. A. (2004). Long-term effects of child corporal punishment on depressive symptoms in young adults: Potential moderators and mediators. Journal of Family Issues, 25(6), 761-782.

*Twum-Danso, A. (2010). Children's perceptions of physical punishment in Ghana. (Nuffield Foundation).

UNICEF (2005). Changing a harmful social convention: Female genital mutilation/cutting. Florence: UNICEF Innocenti Research Centre.

"UNICEF (2010). Child disciplinary practices at home. Evidence from a range of low-and middle-income countries, New York: UNICEF.

UNICEF (2014). Hidden in plain sight. A statistical analysis of violence against children. New York: UNICEF.

United Nations Committee on the Rights of the Child (2006). General Comment No. 8 (2006): The right of the child to protection from corporal punishment and other cruel or degrading forms of punishment, UN document $\mathrm{CrC} / \mathrm{C} / \mathrm{GC} / 8$, Office of the High Commissioner for Human Rights, Geneva. (2 March 2007).

Valdebenito, Eisner, M., Farrington, D. P., Ttofi, M. M., \& Sutherland, A. (2018). Schoolbased interventions for reducing disciplinary school exclusion: A systematic review. The Campbell: Collaboration.

*VanderEnde, K., Amin, S., \& Naved, R.T. 2014 Community-level correlates of physical violence against unmarried female adolescents in Bangladesh, BMC Public Health, 14(1027), 1-7.

*Vu, T. T. H. (2016). Understanding children's experiences of violence in Viet Nam: Evidence from young lives. Innocenti Working Papers no. IWP_2016_26. Florence: UNICEF Office of Research - Innocenti.

Wilson, C. M., Wilson, L. C., \& Fox, C. A. (2002). Structural and personal contexts of discipline orientations of Guyanese parents: Theoretic and empirical considerations. Journal of Comparative Family Studies, 33(1), 1-13.

Zolotor, A. J., \& Puzia, M. E. (2010). Bans against corporal punishment: A systematic review of the laws, changes in attitudes and behaviours. Child Abuse Review, 19, $229-247$. 